Article

\title{
Contemplative Practice, Doxographies, and the Construction of Tibetan Buddhism: Nupchen Sangyé Yeshé and The Lamp for the Eye in Meditation
}

\author{
Manuel Lopez \\ Department of Humanities, New College of Florida, 5800 Bay Shore Road, Sarasota, FL 34243, USA; \\ mlopezzafra@ncf.edu
}

Received: 10 October 2018; Accepted: 10 November 2018; Published: 14 November 2018

check for updates

\begin{abstract}
In this article, I would like to reframe our understanding of the role played by doxographies or classification of views (Skt. siddhānta, Ch. panjiao 判教, Tib. grub mtha') in the Buddhist tradition as it pertained to Tibetan attempts at defining and organizing the diversity of Buddhist contemplative practices that made their way into Tibet since the introduction of Buddhism to the Tibetan plateau in the seventh century, all the way up to the collapse of the Tibetan Empire in the ninth century. In order to do that, this article focuses on one such doxography, the Lamp for the Eye in Meditation (bsam gtan mig sgron), composed in the 10th century by the Tibetan scholar Nupchen Sangyé Yeshé. The first part of the article will place Nupchen's text in the larger historical and intellectual context of the literary genre of doxographies in India, China, and Tibet. The second part of the article will argue that Nupchen used the doxographical genre not only as a vehicle for organizing and articulating doctrinal and contemplative diversity, but also as a tool for the construction of a new and original system of Tibetan Buddhist practice known as 'the Great Perfection' (rdzogs chen). Finally, and as a small homage to the recent passing of the great religious studies scholar Jonathan Z. Smith, I would also like to reflect on the importance that the issues of definition, comparison, and classification-central concerns of Nupchen's as well as of Smith's works-have in creating and articulating religious difference.
\end{abstract}

Keywords: doxography; meditation; non-conceptuality; Nyingma; philosophy; comparison; classification; Jonathan Z. Smith

\section{Introduction: What Is Meditation?}

In his study of the diversity of contemplative practices that had arrived in Tibet from various parts of Asia (India, Nepal, Central Asia, China) during the early introduction of Buddhism to the Tibetan plateau between the seventh and the ninth centuries, Herbert Guenther made the following noteworthy remark:

While it will be readily admitted that 'meditation' has always played a major role in what is generically termed Buddhism, what the Buddhists themselves understood by 'meditation' is not so readily apparent.

Herbert Guenther (1983, p. 351)

As the Princeton Dictionary of Buddhism makes clear, "[T] here is no single term in Buddhism that corresponds precisely to what, in English, is called 'meditation',"1 but the term usually renders

1 There is no single term in Buddhism that corresponds precisely to what in English is called 'meditation.' Some of its connotations are conveyed in such Buddhist terms as bhāvanā, chan, dhyāna, jhāna, patipatti, samādhi, zuochan. See the entry for 'meditation' in Buswell et al. (2014). 
either the Sanskrit term $d_{h y \bar{a} n a^{2}}$ or 'meditative absorption', or the other Sanskrit term bhāvana $\bar{a}^{3}$ or 'cultivation'. Whatever the precise Sanskrit equivalent, though, Guenther's remark stands, and reflects a powerful paradox at the heart of the Buddhist tradition. On the one hand, Buddhism established, at least rhetorically, its very own foundations on the transformative meditative experience that Siddharta Gautama, the Buddha, had over 2500 years ago sitting under the bodhi tree while searching for the ultimate answers to his disillusionment with the world and the human condition, eventually culminating with his experience of enlightenment. ${ }^{4}$ At the same time, as Guenther also points out, and as anyone who has even a superficial knowledge of various forms of Buddhist practice, what Buddhists meant (and mean) by 'meditation', how to define it, how it should be practiced, and even its final goal, became a constant issue of contention over the centuries.

'Meditation' is one of those Buddhist concepts that seems to have a foundation of solid rock, particularly in the eyes of believers, but when examined closely it resembles shifting sands. ${ }^{5}$ It is by exploring those shifting sands that I will argue that 'meditation', as a concept as well as a practice, functions as a fertile and contested ground which has allowed the Buddhist tradition to assert an important degree of continuity and unity (at least rhetorically) with the teachings of the Buddha and with that primordial contemplative experience of its founder. At the same time, that same contested nature opened the door to important discontinuities and diversity, as reflected in the emergence of new Buddhist contemplative traditions and schools of thought over the centuries. ${ }^{6}$

One tool used within the Buddhist tradition to articulate this diversity was the genre of doxographies or classification of views (Skt. siddhānta, Ch. panjiao 判教, Tib. grub mtha'). Doxographies played a central role in the expansion of the Buddhist tradition from its native India to other parts of Asia, particularly Central and East Asia, by becoming a tool for organizing the historical and geographical diversity of Buddhist scriptures, as well as of ritual and doctrinal practices that developed over time. In China, for example, Peter Gregory has argued that "doctrinal classification has often been said to be the hallmark of Chinese Buddhism". 7 Gregory, though, focused mostly on the sectarian purposes of doxographies, and claimed that they served very specific "hermeneutical, sectarian,

2 See the entry for "Dhyāna" in Buswell et al. (2014): "Dhyāna. (P. jhāna; T. bsam gtan; C. chan/chanding; J. zen/zenjō; K. š̆n/sŏnjŏng). In Sanskrit, 'meditative absorption', refers to specific meditative practices during which the mind temporarily withdraws from external sensory awareness and remains completely absorbed in an ideational object of meditation." Gómez, in his definition of meditation in the Encyclopedia of Buddhism, equates "meditation" with "dhyāna": see "meditation" entry by Gómez in Buswell (2004).

3 See the entry for "Bhāvanā" in (Buswell et al. 2014): “(Tib. sgom pa; Ch. xiuxi; Jap. shujū; Kor. susŭp). In Sanskrit and Pāli, "cultivation" (lit. "bringing into being"), a Sanskrit term commonly translated into English as "meditation." It [ ... ] has a wide range of meanings including cultivating, producing, manifesting, imagining, suffusing, and reflecting. It is in the first sense, that of cultivation, that the term is used to mean the sustained development of particular states of mind." Germano and Waldron equate "meditation" with bhāvanā in their entry to "Buddhist Meditation" in the Encyclopedia of Religion. See (Jones et al. 2005).

4 The classic biographies of the Buddha, such as Aśvaghoșa's Buddhacarita, and the Lalitavistara Sütra, maintain a dramatic tension between his birth already as a Buddha, and his life as a human and ultimate experience of enlightenment under the Bodhi Tree. Despite a tradition of the Buddha as an already-enlightened being, as found in those narratives, there is no doubt that the experience of enlightenment marks a before and after in the life narrative of the Buddha. On this particular tension, see (Silk 2003).

5 Luis Gómez uses this notion of "shifting sands" to define a different key Buddhist concept, "Nirvāna", but his ideas equally apply to our exploration of the concept of meditation. For Gómez, "Nirvāna" "has acquired a patina that makes many assume its meaning is obvious. Yet, it is a word about which Buddhists themselves have never reached agreement." Following Gómez, "it may be that when we ask: 'What is Nirvāna?' [or in our case, "What is Meditation"?] we seek to answer the wrong question. Instead we need to ask: How have Buddhists used the term? With what polemical or apologetic purposes? What human aspirations might these uses reveal?" See his "Nirvāna" entry in the Encyclopedia of Buddhism in (Buswell 2004).

6 Before I continue with my argument, let me add a caveat: I am not suggesting here that "meditation", or "meditative experience", is the essence of Buddhism. Robert Sharf has pointed out in his work the dangers of reconstructing the Buddhist tradition through what he considers a Western obsession with the notion of experience that he traces back to William James and his The Varieties of Religious Experience. For Sharf, "[W]hile meditation may have been important in theory, it did not occupy the dominant role in monastic and ascetic life that is sometimes supposed." See (Sharf 1995). What I do argue, though, is that the concept of "meditation" has functioned as an important marker that has helped define boundaries between various Buddhist traditions.

7 He also adds: "Although this judgment is surely one-sided-ignoring as it does many rich areas of more 'popular' developments-it is certainly no exaggeration when applied to Chinese Buddhist scholastic writing. Doctrinal classification 
and soteriological purposes. That is, [doxography] organized into a coherent and internally consistent doctrinal framework the diverse corpus of [Buddhist] sacred scriptures [...]; it legitimized the claims of different [Buddhist] traditions to represent the supreme, orthodox, or most relevant teaching of the Buddha; and it provided a map of the Buddhist path". ${ }^{8}$ Chanju Mun expanded this important but narrow understanding of doxographies by adding what he calls an "ecumenical" type of doxographies, or classification of views that were not so worried about establishing sectarian differences, and more focused on articulating and integrating a universal type of Buddhist discourse. ${ }^{9}$ Jacob Dalton, in his overview of late Indian and early Tibetan doxographies, highlighted the role that these texts had in articulating Buddhist ritual and doctrine during the emergence of Tantra in India in the eighth century, as well as in articulating and organizing the ritual and doctrinal diversity of Buddhist practice as it was being introduced in Tibet beginning in the ninth century.

In this article, I would like to expand our understanding of the role of doxographies in the Buddhist tradition by examining Tibetan attempts at defining and organizing the diversity of Buddhist contemplative practices that made their way into Tibet since the introduction of Buddhism on the Tibetan plateau in the seventh century, all the way up to the collapse of the Tibetan Empire in the ninth century. In order to do that, I want to focus on one such doxography, the Lamp for the Eye in Meditation (bsam gtan mig sgron), ${ }^{10}$ composed in the 10th century by the Tibetan scholar Nupchen Sangyé Yeshé. As part of my main argument, I will use Jonathan Z. Smith's understanding of the concepts of definition, comparison, and classification to explore how Nupchen used the doxographical genre not only as a vehicle to organize and articulate doctrinal and contemplative diversity, but also used it as a tool that allowed him to claim the superiority of a new and indigenous system of Tibetan Buddhist practice known as the Great Perfection (rdzogs chen), while legitimizing it within the larger context of Buddhist contemplative systems. Following Jonathan Z. Smith, I will also argue that Nupchen was not only describing in the Lamp Buddhism as he saw it, but he was interpreting Buddhism as he imagined it, playing a central role during this period into the transformation of Buddhism from a foreign, imported tradition, into something new: Tibetan Buddhism.

\section{Doxographies: The Role of Comparison and Classification in the Construction of Buddhism}

The term doxography was coined by the German classical scholar, Hermann Alexander Diels, to describe the work of classical historians that included discussions of Greek and Roman philosophers of the past. ${ }^{11}$ Modern Buddhist scholars have adopted this term to describe a similar genre within the Buddhist tradition called siddhānta in Sanskrit, panjiao in Chinese (判教), and grub-mtha' in Tibetan. ${ }^{12}$

is one of the most striking features of Chinese Buddhist scholasticism, and it is impossible to understand how medieval Chinese Buddhist scholars thought without understanding panjiao." (Gregory 1987, p. 93).

10 Henceforth referred to as 'the Lamp'.

11 (Zhmud 2001).

12 I would like to add, though, an important terminological clarification. Following most of the scholarship on this subject, this article will use the term doxography in order to describe these Buddhist systems of doctrinal classification. Doxography means etymologically to "write the views", and its origins are attributed to the Greek tradition. The term describes a literary genre in which views of past philosophical systems are organized, usually, in some sort of historical fashion. The use of this term in the context of Indian, Tibetan, and Chinese classification of views, quickly shows that the term does not always describe accurately the nature and goals of these texts. In India the term used for this genre of literature is siddhānta, in Chinese panjiao (Ch. 判教), and in Tibetan they are called grub mtha'. In all cases the meaning generally refers to the description of systems of practice (of realization, literally). There are some general similarities among these Buddhist terms, but there are also important differences. In some of the early classifications (especially in the Indian ones) the main goal was not to classify hierarchically, but to argue specific doctrinal or philosophical views. That is why some scholars are proposing that the term summa may be more accurate to describe the siddhānta or grub mtha' literature. On these issues see (Mestanza 2005, p. 85). To clarify these issues is beyond the scope of this article, but it is important to point out that we need to be careful when using Western terminology to describe Buddhist categories, since they bring with them unintended meanings to the object of our study. Another issue related to the use of the term doxography is the problem of determining what counts as one. In most of the scholarship reviewed, we find that the study of classificatory Buddhist systems usually begins with the earliest one that has survived, Bhāvaviveka's Madhyamakahrdayakārikā. But what about the classification of 


\subsection{Doxographies: Solving a Buddhist Hermeneutical Problem}

As Gregory pointed out in his study of Chinese doxographies, the importance of the genre within the Buddhist tradition should not be underestimated, since it responded to a very important hermeneutical problem at the core of the constant emergence of new texts, rituals, and practices. ${ }^{13}$ Lopez traces the root of this problem to the Buddha himself and, in particular, to the conundrum presented to his followers in some of the Buddha's last words before his death. ${ }^{14}$ These words are presented in the poignant scene in the Mahäparanibbanasutta, in which the Buddhist community is witness to the imminent death of the Buddha:

Then [the Buddha] addresses the venerable Ānanda: “It may be, Ānanda, that some of you will think. 'The word of the Teacher is a thing of the past; we have now no Teacher.' But that, Ānanda, is not the correct view. The Doctrine and the Discipline, Ānanda, which I have taught and enjoined upon you, is to be your teacher when I am gone".

\section{Mahāparanibbanasutta $60^{15}$}

For over 40 years, the Buddha had created a community that relied on him not only as their teacher, as the transmitter of the truth he had discovered under the Bodhi tree, but also as its interpreter. Whenever there was a doubt about the possible meaning of his teachings, the community could always confer with the Buddha, and the Buddha could offer a definitive answer that settled any existing doubts. After his death, though, the community, as the Mahāparanibbanasutta makes clear, is not only sad about the departure of their teacher, but they are also deeply worried about how to preserve the meaning of his words and, most importantly, how to retrieve it. While the language of his teachings may have appeared, at times, equivocal, the Buddha always could guarantee the stability of its meaning.

The moment described in the above quote also signals, as Donald Lopez has argued, the very beginning of Buddhist hermeneutics, since, as he pointed out, "[T] hose who are not yet enlightened must interpret". ${ }^{16}$ On the one hand, the Buddha ensures in the Mahäparanibbanasutta the continuity of his teachings, since "the teaching [ ... ] is to be your teacher". On the other hand, he also opens the door to interpretation, as he does not explain what this statement exactly means. This tension is very important in understanding the development of Buddhism over the next 2500 years, particularly the way in which it has allowed the tradition to preserve a certain degree of unity within an astonishing degree of doctrinal, soteriological, and ritual diversity.

The notion that the teaching is the teacher allows the later Buddhist tradition a great degree of freedom to determine what the teachings of the Buddha are. At the same time, Buddhists over the centuries had to develop a series of interpretative strategies in order to allow the tradition to rein in that plurality of understandings under the umbrella (even if this was a rhetorical one) of the unity of all the teachings of the Buddha. This is not the place to discuss some of the mechanisms that the

Buddhist systems found in the earlier Samdhinirmocana Sūtra? This sūtra presents a hierarchical classification, in the form of the Three Turnings of the Wheel, and it is also polemical, arguing the superiority of Yogācāra over other Buddhist teachings. The point here is not to deconstruct the notion of doxography (or siddhānta, or grub mtha') to the point that it is not useful anymore. The goal is just to make us aware of the constructed nature of the term, and the fact that we need to be aware of the fluidity of the category as it was used differently in different historical and cultural contexts. Dalton also makes an interesting point when he says that another important difference between Western doxographies and Indian ones is that "whereas the former are generally philosophical works and restrict themselves to the views held by each school, the tantric classification systems of India [ . . . ] are largely concerned with differences in ritual practice", see (Dalton 2005, p. 119). Additionally, for important studies of the doxographical genre in Buddhism, see (Hopkins 1996; Mun 2006; Eimer 1992; Gregory 1987).

13 (Gregory 2002, p. 20).

14 (Lopez 1988, pp. 1-2).

15 (Warren 1973, p. 107).

16 (Lopez 1988, p. 9). 
Buddhist tradition developed in order to solve this hermeneutical tension, ${ }_{1}^{17}$ but I want to highlight in this section the important role that doxographies played in articulating key differences between various Buddhist traditions, integrating different doctrines, rituals, and practices within a cohesive system, while organizing those differences hierarchically in order to establish the superiority of certain doctrinal developments in contrast to competing or old ones.

The various functions of the doxographical genre are a reflection of its simultaneous descriptive and prescriptive nature. On the one hand, we can examine these texts and trace the evolution of Buddhism in India, China, as well as Tibet. Doxographies then can be seen as describing a historical process. At the same time, we can see doxographies as a narrative written with clear agendas by various competing Buddhist groups that were attempting not only to organize (sometimes contradictory) ritual and doctrinal systems, but also to prescribe a particular doctrinal or sectarian point of view. ${ }^{18}$ Doxographies were, from this perspective, tools to create an ideological reality. Being able to see where these two aspects intersect, as well as when they differ, is one of the important roles in our scholarly research of these texts.

A quick overview of the history of Buddhist doxographies in India, China, and Tibet, will help us to better contextualize the contents of Nupchen's Lamp for the Eye in Meditation, as well as his goals when writing it. ${ }^{19}$ Not all the doxographies discussed in this brief summary had a direct influence on Nupchen's Lamp, but I have included them because I want to highlight the role that doxographies had all over Asia in making sense of the constantly changing Buddhist tradition, as well as its constantly evolving and constructed nature. The goal of this overview is also to show how Nupchen used the doxographical genre not only to passively organize the various forms of Buddhism that were imported into Tibet during his time, but also to actively and creatively engage in the construction of a unique Tibetan Buddhist view. Nupchen was, ultimately, a deeply innovative thinker working within a very traditional framework.

\subsection{Indian Precedents}

In India, doxographies were originally used as an intellectual tool to define Buddhist positions against non-Buddhist traditions. ${ }^{20}$ The emergence over time of discrepancies in the interpretation of certain Buddhist ideas forced doxographies to eventually incorporate various intra-sectarian doctrinal issues. In the earlier form, doxographies were articulated around the discussion of particular doctrinal or philosophical views in which the Buddhist view always prevailed against non-Buddhist positions. When Buddhist doxographies shifted mainly to discussions of different Buddhist philosophical views (with non-Buddhist traditions being peripheral to the main argument of the text or not even included), we see a shift in the genre to a hierarchical organization of those diverse philosophical

17 Regarding some of the most important hermeneutic strategies developed by Buddhism to solve this tension, see (Lopez 1988).

18 For an understanding of history as narrative, see (Jenkins 2003).

19 Here, I will not discuss Japanese doxographies since they did not have a direct influence in the Tibetan world, which is the focus of my article. The doxographical genre, nonetheless, also played a major role in the process of assimilation of Buddhism in Japan. In Kūkai's works (Kūkai 1972, 774-835 CE), for example, we see the use of doxography as a way to articulate the superiority of the Shingon tradition over the Tendai school. For Kūkai's use of doxography, see (Hakeda 1972). In his discussion of Kūkai and Shingon, McMullen also argues that "esoteric Buddhist scholasticism emphasized the tools of doxography, taxonomy, and lineage in an effort to explicate the secret teachings of the buddha. However, which texts, teachings, and lineages were 'esoteric' has always been a matter of debate." See (Mcmullen 2016). Kūkai's contemporary and founder of the Tendai school, Saicho (767-822 CE), will also use doxographical classifications in order to argue the superiority of Tendai over that of rival schools. I want to thank Prof. Paul Groner for his insights on the use of doxographies in Japan.

20 Although there were also non-Buddhist examples such as Śankarācārya's Brahmasūtrabhāṣya, which "sets forth the views of nasstika (heterodox) and āstika (orthodox) schools and shows the weaknesses and strengths in each as a strategy to demonstrate the superiority of Śankara's own Advaita Vedānta philosophy. None of these Indian works were written simply as informative textbooks about the tenets of different Indian schools of thought. They instead have clear polemical agendas: namely, demonstrating the superiority of their own position, and showing how the lesser philosophies are either a hindrance or a stepping stone to their own philosophy, as revealed by the Buddha in the case of Buddhist siddhānta, and by the Vedas in the case of non-Buddhists." See Śankarācārya entry in (Buswell et al. 2014). 
positions. Doxographies, as a literary genre, offer Buddhism a structure in which diversity could be interpreted and organized, arguing for the unity of the Buddhist path, while allowing space for new and diverse interpretations. For reasons of space, I will only refer to the most important examples of the doxographical genre in India, mainly those of Bhāvaviveka, Sāntarakṣita, Buddhaguhya, and Vilāsavajra, which will give us a sense of the evolution of late Indian tantra and the attempts to organize new ritual systems of practice into cohesive, clearly organized, hierarchical schemes. ${ }^{21}$

\subsubsection{Bhāvaviveka's Madhyamakahṛdayakārikā (500-570 CE)}

Bhāvaviveka (500-570 CE)'s Madhyamakahrdayakārika ${ }^{22}$ with its auto-commentary, the Tarkajvālā, is traditionally considered by scholars to be the earliest extant Indian Buddhist doxography (although, as we will see, there were earlier Buddhist doxographies in China). He is believed to have been influenced by Indian scholar and grammarian, Bhartṛhari. ${ }^{23}$ The Madhyamakahrdayakārika offers a detailed discussion of the most important schools of thought, Buddhist as well as non-Buddhist, that were influential during Bhāvaviveka's time. ${ }^{24}$

The structure of the work does not follow the hierarchical organization that will be common in later doxographical systems. Bhāvaviveka seems more concerned with arguing specific doctrinal points against non-Buddhist traditions than in ranking those traditions hierarchically. Nonetheless, we already find in the Madhyamakahrdayakārikā vigorous internal Buddhist debate between the Svātantrikas, of which Bhāvaviveka is considered one of the earliest proponents, and the Prāsangikas, whose position was defended by Buddhapālita. ${ }^{25}$

Although later Buddhist doxographies will differ in content as well as in structure, there is no doubt that we find in Bhāvaviveka the foundation for a new way of thinking within the Indian Buddhist tradition. Doxographies will be used, from then on, to argue within the Buddhist tradition in the same way that had been used in the past to argue against the doctrinal issues of other religious traditions. Buddhism will gradually become more concerned about the internal structure and importance of its own teachings than in arguing against other traditions. ${ }^{26}$

\subsubsection{Sāntarakṣita's Tattvasangraha (725-788 CE)}

Śāntarakșita's Tattvasangraha ${ }^{27}$ can be considered one of the earlier (if not the earliest) Indian doxographical systems to make it onto the Tibetan plateau. Śāntarakșita is considered, after all, the first abbot of Samyé monastery and had a very important role in the introduction of the monastic and, by extension, scholastic Buddhist tradition into Tibet. ${ }^{28}$ Sanntarakșita's work, especially as transmitted

21 For a thorough analysis of the doxographical genre, particularly in the Indian and Tibetan contexts, see (Dalton 2005).

22 His work has been translated by (Eckel 2008).

23 See (Dalton 2005, p. 119). His source is (Halbfass 1988, p. 268).

24 Chp. 4 is an analysis of the determination of reality according to the Śāvakas; Chp. 5 is an analysis of the determination of reality according to the Yogācārins; Chp. 6 is an analysis of the determination of reality according to the Sāmkhya; Chp. 7 is an analysis of the determination of reality according to the Vaiśeșika; Chp. 8 is an analysis of the determination of reality according to the Vedānta; Chp. 9 is an analysis of the determination of reality according to the Mīmāmsā. See (Eckel 2008).

25 Although Bhāvaviveka and Buddhapālita disagreed on the nature of Madhyamaka, I am aware that the categories of Svātantrika vs. Prāsañgika Madhyamaka were created only retrospectively and were still not defined as philosophical systems during Nupchen's time. For further discussion on this issue, see (Hopkins 1987; Dreyfus and McClintock 2002).

26 Dalton has this to say about the influence of Bhāvaviveka: "[A]t first the doxographic paradigm was resisted by many within Buddhism, but it was part of a deep and irresistible trend that was sweeping through Indian thought; by the seventh century Candrakīrti could have argued against doxography, but only on its own terms." In (Dalton 2005): "A Crisis of

27 (Jha 1937). Doxography: How Tibetans Organized Tantra During the 8th-12th Centuries", p. 119.

28 Although other early sources such as the Testament of Ba (Tib. sBa bzhed) mention Ba Selnang (Tib. sBa gsal snang) as the first abbot of the monastery. See (Pasang Wangdu et al. 2000; Van Schaik and Iwao 2008). 
into Tibet by his main disciple, Kamalaśîla, ${ }^{29}$ will be enormously influential to Nupchen, especially in his understanding of what he labeled as "the Gradual Vehicle" in the Lamp for the Eye in Meditation. ${ }^{30}$

Śāntarakṣita's Tattvasangraha, following Bhāvaviveka's Madhyamakahrdayakārikā, does not offer a hierarchical classification of philosophical views, but presents an overview of important philosophical concepts and the way they were understood by various Buddhist, as well as non-Buddhist schools, like the Nyāya, Mìmāmssā, Sāmkhya, Jainas, and the Aupanișadikas, as well as of some Buddhist traditions like the Vātsīputrīya. ${ }^{31}$

In retrospect, we can see the Tattvasangraha as part of a transitional period in the history of Buddhism. Sāntarakșita's Tattvasangraha reflects a Buddhism in which external debates still overshadow internal Buddhist tensions. It is also important to point out the lack of any meaningful discussion of tantric systems, especially since these systems are thriving during this period and will become the center of any doxographical discussion in the upcoming decades.

\subsubsection{Buddhaguhya's Commentaries to the Mahāvairocana-Abhisambodhi Tantra (Eighth Century)}

In the eighth century, the Indian scholar Buddhaguhya wrote two different doxographical classifications that can be found in his two commentaries on the Mahāvairocana-abhisambodhi Tantra, ${ }^{32}$ and are structured around a twofold system that differentiated Mahāyāna and tantric teachings. He also included a division within the tantric teachings of Kriyā and Yoga Tantras. ${ }^{33}$

With Buddhaguhya, we clearly see that Buddhist doxographical classifications are taking a new direction from the one we have seen in the works of Bhāvaviveka and Śāntarakṣita. We see this in five main areas: First, Buddhaguhya's writings are not as concerned in arguing against non-Buddhist views as in trying to make sense of the enormous variety of new Buddhist teachings being produced during his time. Second, he also proposes a clear separation between Mahāyāna teachings and the new cycles of tantric teachings being produced in India. Third, he is one of the first Buddhist scholars to focus mainly on tantra, making all other previous Buddhist teachings merely introductory or peripheral to the new tantric cycles. Fourth, we can also see a change of attention from doctrine to ritual concerns, which Dalton sees as the central feature of Tantric doxography. ${ }^{34}$ Even if we argue for the profound doctrinal relevance of these new ritual vehicles, the new classification will pay attention to ritual aspects in order to organize them. Fifth, Buddhaguhya classifies the new tantras around a dichotomy that will become very important in later tantric thought: external vs. internal tantras. This

29 Kamalaśĩla (740-95), Sāntarakṣita's most important student, wrote an important commentary to Śāntarakṣita's Tattvasañgraha, the Tattvasamgrahapañjikā, although he did not add any major doctrinal changes to Śāntarakṣita's text. He became a relevant figure in Tibetan history due to his role in the so-called Samyé Debate in which he defended the views of the gradualist tradition, represented by his teacher Śāntarakșita, against the 'Sudden Approach', represented by Chan and defended by the Chinese monk known as Hashang Mahāyāna. The historicity of the debate has been called into question by some scholars, see (Van der Kuijp 1984, ; Ruegg 1989, who called it a "dehistoricized topos"), but there is no doubt that the narrative about the debate framed what was considered an important tension in early Tibetan Buddhism, mainly the methods by which to achieve enlightenment. Some important sources for the debate are (Demiéville 1952; Tucci 1956; Houston 1980; Faber 1986). On the issue of the Samyé Debate and its connection to doxographical classifications (see Ruegg 1989).

30 Ruegg provides the following description of Śāntarakșita's classification: Chapters 1-3 offer discussion of the Sāmkhya prakrti and theory of causation and discuss the concept of God; Chapter 4 examines the doctrine of a world endowed with own being; Chapter 5 is an examination of the theory of śabdabrahman; Chapter 6 explores the theory of purusa; in Chapter 7, Śāntarakșita examines the views of Nyāya, Mīmāmssā, Sāmkhya, Jainas, and the Aupanișadikas, as well as the Buddhist Vātsīputrīya's pudgala ideas; Chapter 8 is an analysis of the doctrines of permanent and stable entities; Chapter 9 deals with Karma and the result of actions; Chapter 10 outlines the six categories (padārtha) of Substance (dravya); Chapter 11 is devoted to the notion of Quality (guna); Chapter 12 focuses on Action (karma); and the Chapter 13 discusses the notion of 31 the Universal (sāmānya) (see Ruegg 1989).

31 (Jha 1937).

32 (Hodge 2003, p. 4).

33 To be more specific, Buddhaguhya divides the Buddhist teaching in two: the teachings of the Mahāyāna, focused on the practice of the perfections (pāramitā), and the teachings of Tantra, focused on mantra recitation, which Buddhaguhya subdivides into Kriyā (focused on outward practice or "objective supports") and Yoga Tantras (focused on inward techniques or on the "practice of the profound and vast"). See (Hodge 2003; Dalton 2005, pp. 121-24).

34 (Dalton 2005). 
dichotomy, in which "exterior" practices are inferior to "interior" ones, will help organize new tantras in a hierarchical way. ${ }^{35}$

\subsubsection{Vilāsavajra's Spar Khabs (Eighth Century)}

In the eighth century, the Indian Master Vilāsavajra wrote commentaries to the Chanting the Names of Mañjusrī (Skt. Mañjuśriñāmasamgīti, Tib. 'jam dpal mtshan brjod) and the Guhyagarbha Tantra, in which he offered two different doxographical classifications. The one in the Mañjuśrīnāmasamgìti adds an intermediate category, Caryā, between the Kriyā and Yoga divisions found in Buddhaguhya's commentary to the Mahāvairocana-abhisambodhi. ${ }^{36}$ However, it is the classification in his commentary to the Guhyagarbha Tantra (spar khabs) that deserves special attention, since it has some characteristics that will be very influential for later Tibetan thought. In fact, Vilāsavajra will be one of the main references, together with the ninth century Tibetan scholar, Pelyang, informing Nupchen's understanding of the Mahāyoga tradition.

There are several important aspects to his classification. First, although Vilāsavajra includes some non-Buddhist vehicles, their inclusion is clearly not as relevant as in Bhāvaviveka's or Śāntarakṣita's systems. They seem to simply be included in order to add legitimacy to the later Buddhist systems. Second, we can see the new relevance of the Mahāyoga system with which the Guhyagarbha was first associated. The Guhyagarbha and, especially, its 13th chapter will be highly influential in the development of later tantric systems. Third, and this will be important for our later discussion of Nupchen's Lamp for the Eye in Meditation, we find in Vilāsavajra some of the earliest references to the Great Perfection. Although Vilāsavajra discusses Atiyoga as separate from Mahāyoga, Dalton thinks that "in practical terms [Atiyoga] is still dependent on it". ${ }^{37}$ In the spar khabs, Atiyoga seems to be a separate ritual moment that emerges from Mahāyoga, but not a different vehicle with its separate textual tradition and contemplative practices, as we will see later with Nupchen. Fourth, we also see something that will be very relevant for the later New Schools (gsar ma) traditions, namely, the organization of these tantric vehicles around gender categories: "the male tantras focused primarily on method, the female tantras focusing on wisdom, [plus a category of] neuter tantras". ${ }^{8}$ Fifth, the fact that we can find two different classification systems in Vilāsavajra's writings (something we will also see in Nupchen's corpus) can point to a certain fluidity in the use of these categories during this period, but we can also see how tantra is taking shape in a way that will be clearly recognizable in the later Tibetan tradition.

\subsection{Chinese Precedents}

Tibetan doxographies, due to their interest in Tantric systems, followed Indian models for the most part, but the unusual fourfold classification found in Nupchen's Lamp has made some scholars suggest, as we will see, a possible Chinese influence. ${ }^{39}$ While in India and Tibet, classification systems were organized around doctrinal or ritual issues (especially with the development of tantra), a distinctive characteristic of classification systems in China was that they "were usually arranged around narratives of the Buddha's life, often with the aim of promoting a particular text over all others" ${ }^{40}$ Obviously,

35 In a very different context this inward vs. outward categorization found an echo in the earlier denigration by the Mahāyāna of all the early Buddhist traditions, using the label Hinayāna, or inferior vehicle, to refer to it. The use of these categories in order to articulate ideas can be very powerful since they affect the way we look at those earlier teachings. There is no doubt that earlier Buddhist practitioners did not consider their early practices and rituals as merely outwards and were, probably, a complete soteriological path of their own.

36 (Dalton 2005, pp. 124-25).

37 (Dalton 2005, p. 130). Van Schaik adds that Vilāsavajra "does not give any special precedence to the term $r d z o g s$ chen, and does not employ it in any specific technical sense." See (Van Schaik 2004, p. 170).

38 (Dalton 2005, p. 128).

39 (Dalton and van Schaik 2003; Meinert 2003).

40 (Dalton 2005, p. 116). 
in India and Tibet, texts or cycles of texts were important in doxographical classifications, but at least rhetorically, they were not at the center of these doctrinal battles. I will include a brief discussion of two of the scholars from China and Korea, Huiguan (慧觀) and Chegwan (諦觀) (who lived and composed some of his main works in China), whose doxographies could be seen as having some similarities to the one composed by Nupchen.

\subsubsection{Huiguan (慧觀)'s Five Periods Teachings (五時教) (d. 453)}

Although there are some earlier doxographical classification systems in China prior to the one presented by Kumārajīva's disciple Huiguan (慧觀) (d. 453), ${ }^{41}$ scholars seem to agree that his system, under the name of the Five Periods Teachings (五時教), was one of the first to articulate a uniquely Chinese way of organizing the Buddhist teachings that was particularly influential for the later tradition. $^{42}$

One of the distinctive characteristics of Huiguan's system is that he proposes a division of the Buddhist teachings into sudden approaches (dun jiao 頓教), which correspond to the Huayan Sūtra (Avatamsaka Sütra) and are also identified with Chan, and gradual teachings (jian jiao 漸教), which he divides into five different periods, each one associated with a particular textual tradition. The final classification looks as follows: ${ }^{43}$

1. Sudden Teaching (dun jiao 頓教): corresponds to the Huayan Sütra

2. Gradual Teaching (jian jiao 漸教)

2.1. The three vehicles (as described in the Lotus Sütra) were taught separately by the Buddha

2.1.1. The Four Noble Truths to the Śrāvakas

2.1.2. Interdependent Origination to the Pratyekabuddhas

2.1.3. The Six Perfections to the bodhisattvas.

2.2. The Buddha taught the common teaching of the three vehicles; mainly, the Perfection of Wisdom.

2.3. In the third period, the Buddha made clear the inferiority of the teachings of the Śrāvakas and elevated the teachings of the bodhisattvas. This is mainly found in the Vimalakîrti Sütra.

2.4. During this period, the three vehicles were subsumed under one vehicle. This teaching was presented in the Lotus Sütra.

2.5. The final period, as presented in the Nirvāna Sütra, taught the eternality of the Buddha.

Huiguan is considered to be the first to establish the polemical notions of gradual and sudden as classification categories to organize the various Buddhist teachings, ${ }^{44}$ a reflection of a debate that will be part of the Buddhist intellectual life in China in the following centuries. Even though Huiguan's and Nupchen's understandings of the notion of 'sudden' are quite different, one of the aspects that makes a discussion of Huiguan's classification relevant to our discussion of Nupchen's Lamp is that we will see how this tension between sudden and gradual also plays a central role in Nupchen's doxographical classification. In the Lamp we do not only see a clear distinction between the Indian gradual and the Chinese sudden systems, but even within Mahāyoga there is a distinction between gradual and sudden approaches.

\footnotetext{
41 (Mun 2006; Wu and Wilkinson 2017).

42 (Gregory 2002, p. 111).

43 (Gregory 2002, pp. 111-12).

44 (Gregory 2002, p. 113).
} 


\subsubsection{Chegwan (諦觀)'s Four Types of Content of Buddhist Teachings (化法四教) (d. 971)}

The 10th century classification, the Four Types of Content of Buddhist Teachings (化法四教), developed by the Korean monk Chegwan (諦觀) (d. 971), was not particularly influential in the Chinese tradition, but it is important that we briefly discuss it here, since it has been mentioned as a possible direct influence on Nupchen's Lamp. ${ }^{45}$ Chegwan, just like Nupchen, offers a fourfold scheme that includes, in the two lower levels, the Gradual and the Sudden, while the two upper levels include what he calls Secret and Indeterminate (see Table 1).

Table 1. Comparison of Chegwan and Nupchen's fourfold classifications.

\begin{tabular}{ccc}
\hline & Chegwan & Nupchen \\
\hline 4 & $\begin{array}{c}\text { Indeterminate } \\
\text { (不定教) }\end{array}$ & $\begin{array}{c}\text { Atiyoga } \\
\text { (rdzogs chen) }\end{array}$ \\
\hline 3 & $\begin{array}{c}\text { Secret } \\
\text { (秘密) }\end{array}$ & $\begin{array}{c}\text { Mahāyoga } \\
\text { (rnal 'byor chen po) }\end{array}$ \\
\hline 2 & $\begin{array}{c}\text { Sudden } \\
\text { (頓教) }\end{array}$ & $\begin{array}{c}\text { Sudden } \\
\text { (ston mun cig car 'jug pa) }\end{array}$ \\
\hline 1 & $\begin{array}{c}\text { Gradual } \\
\text { (漸教) }\end{array}$ & Gradual \\
(tsen men rim gyis 'jug pa)
\end{tabular}

Although there are important differences in their understandings of each of those categories, what is relevant to us is the possible structural borrowing of them by Nupchen. This would explain the obvious difference of the Lamp's classification when compared with late Indian systems, which, as we saw, were more concerned with tantric developments than with doctrinal and philosophical issues. The fourfold doctrinal system and the centrality of the tension between sudden and gradual approaches may indicate a certain amount of Chinese influence in the work, and the inclusion of Chinese Chan as one of the Buddhist traditions discussed in the Lamp definitely indicates that Nupchen was quite familiar with the Chinese Buddhist tradition.

There are some issues when trying to suggest some direct borrowing by Nupchen of Chegwan's system. First, Chegwan wrote his classification system at the end of the 10th century in Southern China, and his text did not circulate widely at that time, so it would be difficult to prove that it influenced Nupchen, even though both composed their texts around the same time. Second, the four categories within Chegwan's system are related to methods of teaching and not to actual teachings, as they are in Nupchen's classification. Despite the problematic attribution of direct influence of Chegwan's system over Nupchen's classification, there are enough interesting correlations in both systems that further research on this issue may be needed to settle this point. ${ }^{46}$

\subsection{Early Tibetan Classifications}

It is now time to look at some of the early Tibetan classification systems that preceded the Lamp and that show the way Tibetans were assimilating and reinterpreting late India tantric developments before Nupchen composed his doxography. For the most part, Tibetans will follow Indian doxographical models concerned with late Indian tantric developments, like the ones by Buddhaguhya and Vilāsavajra. Nupchen was also very much part of this process of assimilation of late Indian tantric Buddhism, ${ }^{47}$ but he was also an exception, and proposed in the Lamp an alternative classification

45 For a discussion of Chegwan's classification see (Hu 2014). Also see (Dalton and van Schaik 2003, p. 116; Chappell and Ichishima 1983, pp. 60-61).

46 I want to thank an anonymous reviewer of an earlier version of this article for some clarifications on the problematic nature of the attribution of influence of Chegwan's system on Nupchen's doxography.

47 This is particularly clear in the alternative doxographical classification he wrote in his Armor Against Darkness (Mun pa'i go cha). 
system that did not follow its Indian precedents and had more in common with Chinese doxographical (panjiao) systems.

One of the main differences between the Tibetan and the Indian approaches to the doxographical genre is that while Indian systems were more concerned with organizing and classifying new tantric ritual developments, Tibetans were more interested in doctrinal issues. ${ }^{48}$ This may have to do with the foreign nature of Buddhism in Tibet. Another important aspect of the early Tibetan doxographies is that they show Buddhism in Tibet in a process of creative transformation, before the later Ancient ( rnying $m a$ ) and New (gsar ma) schools settled for standard nine and four vehicle systems, respectively, during the later centuries. ${ }^{49}$

Two of the most important precedents to Nupchen's Lamp were Padmasambhava's Garland of the Views of the Secret Instructions (man ngag lta ba'i phreng ba) and Pelyang's Lamp for the Mind (thugs kyi sgron ma). ${ }^{50}$ The former is important for its connection to the early developments of the Great Perfection tradition as a separate vehicle, an important aspect of Nupchen's Lamp. The latter one will have an important impact on Nupchen's understanding of the Mahāyoga tradition. Nupchen quotes from both of them repeatedly in the Lamp.

\subsubsection{Padmasambhava's Garland of the Views of the Esoteric Instructions (man ngag lta ba'i phreng ba)}

The importance of the Garland of the Views of the Esoteric Instructions ('the Garland' from now on) for our understanding of the early development of Buddhism in Tibet has been extensively discussed by several scholars. ${ }^{51}$ There are a few aspects that make this text relevant: it is considered to be the earliest Tibetan doxography; ${ }^{52}$ its seven vehicle classification is a clear Tibetan precedent to the nine vehicle system later adopted by the Nyingma tradition; and finally, the Garland is also seen as very influential in the formation of the early Great Perfection tradition. The fact that the text is quoted in Nupchen's Lamp testifies to its old pedigree, and although Nupchen does not follow the seven-vehicle classification of the text, he uses it as a source for his understanding of tantric contemplative practices.

The Garland shares with Vilāsavajra's spar khab the fact that both are a commentary of Chapter 13 of the Guhyagarbha Tantra. This complex and obscure chapter proved to be very fertile ground for the development of tantric thought and lead to the early speculations that would be the seeds for the Great Perfection. The text offers a sevenfold classification that, as we can see, follows earlier Indian developments, as discussed in our previous section. The Garland divides all Buddhist views into three main vehicles: the Sūtra, the Outward Tantra, and the Inner Tantra:

Sūtra

1. Śrāvaka

2. Pratyekabuddha

48 (Dalton 2005, p. 116).

49 'In Tibetan, 'Ancient', is the name of one of the four major sects of Tibetan Buddhism. The name derives from the sect's origins during the 'early dissemination' (snga dar) of Buddhism in Tibet and its reliance on translations of Tantras made during that period; this is in distinction to the new (gsar ma) sects of Bka' brgyud, Sa skya, and Dge lugs, all of which arose during the later dissemination (phyi dar) and make use of newer translations. The Rnying ma is thus 'ancient' in relation to the new sects and only began to be designated as such after their appearance." (Buswell et al. 2014).

50 There are other doxographies, both from the eighth century: Yéshé Dé (ye shes sde)'s Differentiating the Views (lta ba'i khyad par) and Kawa Peltsek (ska ba dpal brtsegs)' Esoteric Instructions of the Stages of the View (lta ba'i khyad pa'i man ngag) that I will not be discussing here for lack of space and because they are less relevant for my argument. For Yéshé Dé's text, see (Ruegg 1981). Van Schaik also has argued that Kawa Peltsek's text may not be by him and of later composition, making it irrelevant for our discussion. See (Van Schaik 2004, p. 188).

51 See (Karmay 1988; Dalton 2005), and Germano in two of his unpublished manuscripts, The Secret Tibetan History of Buddhist Tantra in Ancient Tibet and Mysticism and Rhetoric in the Great Perfection.

52 Dalton claims that the text is "our earliest extant text entirely devoted to setting forth a tantric classification system" (Dalton 2005, p. 132). According to Dalton, there is substantial evidence for the attribution of the text to Padmasambhava, see (Dalton 2005, p. 132, n. 41). Ruegg thinks that the first Tibetan doxography is the lta ba khyad par, see (Ruegg 1981), and Takahashi, in her dissertation, proposes Pelyang's Lamp of the Mind (see Takahashi 2009). 
3. Bodhisattva

Outward Tantra

$\begin{array}{ll}\text { 4. } & \text { Kriyā } \\ \text { 5. } & \text { Ubhayā } \\ \text { 6. } & \text { Yoga }\end{array}$

Inward Tantra

$\begin{array}{ll}\text { 7. } & \text { Mahāyoga } \\ \text { a. } & \text { Generation } \\ \text { b. } & \text { Perfection } \\ \text { c. } & \text { Great Perfection } \\ \end{array}$

Here, as we saw in the late Indian tradition developments, Yoga Tantra is pushed into the Outward Tantra, showing that during this period the system is still very much in play, with newer developments rapidly pushing aside (or outside, or lowering, depending on the image the text wants to present) older ones. What we find here, though, at least in regard to Inward Tantra, is not yet a system of separate vehicles, but a blueprint for a gradual, integrated system of meditation that outlines the different stages of contemplative practice. The Great Perfection tradition during this period is still part of a broader system of ritual practice and contemplation. ${ }^{54}$

\subsubsection{Pelyang's Lamp for the Mind (thugs kyi sgron ma, Late Eighth-Early Ninth Centuries) ${ }^{55}$}

Pelyang's doxographical system also shows clear Indian precedents (particularly Buddhaguya), although, unlike the Garland, his main concern is the Mahāyoga tradition. As we have said, it is very difficult to know if this classification is earlier or later than the Garland, but, nonetheless, an examination of these two texts, which were probably composed very close to each other in time, shows that Tantra is undergoing a very creative period, with new developments continuously emerging and with various classification systems trying to articulate this evolution in some sort of cohesive way.

Pelyang's Lamp for the Mind includes, again, non-Buddhist as well as Buddhist philosophical views. ${ }^{56}$ We can also see some Chinese influence in Pelyang's system in his inclusion of a vehicle of Gods and humans, which is common in many early Chinese doxographies. Dalton also points out the fact that while the Garland had mainly a ritual focus, following Indian models, Pelyang's focus is doctrinal, showing a new Tibetan sensibility that seems to pave the way for the philosophical approach of Nupchen's Lamp. 57

We can see Pelyang's influence on Nupchen's Lamp on two different levels. On a more general one, Nupchen's Lamp shows the doctrinal concern of Pelyang in his presentation of the four different

\footnotetext{
(Dalton 2005, pp. 124-31).

(Dalton 2005, p. 88).

For an excellent study of Pelyang's life and works, see (Takahashi 2009).

56 The final classification looks like this: (1) Gods and humans, (2) Śrāvakas, (3) Pratyekabuddhas, (4) Bodhisattvas, (5) Tantras (these divided in (a) Kriyā, (b) Upāya, (c) Yoga, (d) Mahāyoga). See (Dalton 2005, p. 137).

57 Takahashi agrees with this portrayal of Pelyang's classification: "The first half of the Lamp of the Mind is a Buddhist doxographical presentation of non-Buddhist and Buddhist systems, refuted or criticized in the standard hierarchical progression of lower to higher systems, ending with a summation of the highest system. In this light Dpal dbyangs's work is nothing out of the ordinary. However, while most Indian Buddhist tantric doxographies center on distinctions in the rituals of the various Tantras, Dpal dbyangs's Lamp of the Mind hardly mentions ritual. The distinctions that concern Dpal dbyangs are exclusively related to view; he does not comment on the role of ritual in distinguishing whether a system is effective. Furthermore, although later Tibetan doxographies resemble Dpal dbyangs's Lamp of the Mind in relying upon view and perspective, rather than practice or ritual for their rankings, it appears that Dpal dbyangs's Lamp of the Mind is among the first, and perhaps the oldest, extant Tibetan doxography to do so. Once again, Dpal dbyangs appears to have been an innovator among Tibetans in this field." (Takahashi 2009, p. 104).
} 
vehicles and, in fact, he has no interest in the ritual aspects of the various traditions he discusses. A more direct influence can be seen in Nupchen's particular presentation of the Mahāyoga tradition, which is strongly influenced by Pelyang's works, as these are cited frequently in the Lamp. Nupchen, just like Pelyang, will avoid, for the most part, any discussion of the sexual or violent rhetoric of the tradition and instead will focus on its more philosophical aspects.

\section{Nupchen Sangye Yeshe: Writing the Lamp for the Eye in Meditation to Bring Light into the Darkness}

Dalton has pointed out that "Chinese panjiao systems [ ... ] reflect cultural interests and anxieties that were uniquely Chinese. The panjiao often tells us less about the Indian Buddhist teachings that they organize than about the Chinese concerns that were at stake in the Sino-Indian encounters." 58 This will also be the case in Tibet, which is why, if we want to understand Nupchen's Lamp for the Eye in Meditation and its importance in the establishment of a unique understanding of the Buddhist path in Tibet, it is important to look at the biographical and historical context in which it was written.

We are not sure about Nupchen's dates, although we can roughly situate him between the mid-9th and mid-10th centuries. ${ }^{59}$ Various accounts present us with a figure deeply engaged in the intellectual Buddhist world of the 9th-10th centuries, traveling to India, Nepal, and Central Asia from a very young age, learning from a wide variety of teachers, collecting and translating texts, and composing commentaries and treatises on some of the most cutting-edge Buddhist literature of the period, such as that of the Anuyoga and the Great Perfection traditions. He was also central in articulating a coherent vision for the Great Perfection drawing from the earliest textual corpus of the tradition, the Eighteen Texts of the Mind (Tib. Sems sde bco rgyad). ${ }^{60}$ He was also a unique witness to the political events that unraveled after the collapse of the Tibetan Empire in the mid-ninth century. One of the most famous stories about him involves a (probably) fictitious encounter with Langdarma ( glang dar ma), who is traditionally portrayed in Buddhist sources as responsible for the persecution of Buddhism in the ninth century that almost erased the Buddhist tradition from the Tibetan plateau. In a short biographical account by the 18th century Tibetan scholar Guru Tashi ( $g$ u ru bkra shis) the encounter is described as follows (the translation is mine):

At the time when King Langdarma was destroying the teachings of the Buddha [Nupchen] scared this evil king. The king asked him: "What powers do you have?" and Sangyé Yeshé replied: "Look at the power of my mantra!" [ . . ] ] He pointed his index finger towards a rock, and a lightning bolt destroyed it into pieces. Then, the terrified king said: "I will not harm your followers!" It is clear that due to Sangyé Yeshé's kindness the mantrins with white robes and long hair were not harmed and, in general, [this was of] great benefit to the teachings of the Buddha. ${ }^{61}$

In another episode described in an alleged autobiography, we find a further instance in which he uses again wrathful mantras (what some people may call "black magic") ${ }^{62}$ in order to kill a group of soldiers who were surrounding a fortress in which Tibetan monks were looking for shelter. ${ }^{63}$ The figure

58 (Dalton 2005, pp. 115-16).

59 One of the first problems we face when studying the life of Nupchen is the uncertainty surrounding his dates. For a detailed discussion of this issue as discussed in Tibetan as well as Western sources, see (Lopez 2014).

60 For a history of the Mind Series literature, see (Lopez 2018).

61 The Tibetan is "khyad par du rgyal po glang dar mas sangs rgyas kyi bstan pa bshig pa'i dus slob dpon 'dis rgyal po sdig can skrag par mdzad de/rgyal pos khyod la nus pa ci yod zer bas ngas sngags tsam bzlas pa'i nus pa 'di la gzigs shig ces [... ] da dung nus pa 'di la gzigs shing zer nas sdigs mdzub kyis thog phab ste pha ri'i brag la bsnun pas tshal bar song/der rgyal po 'jigs shing skrag nas khyed "khor bcas la gnod pa mi byed do zer nas btang ste/sngags 'chang gos dkar lcang lo can rnams la gnod pa ma byung na khong gi drin du mngon te sangs rgyas kyi bstan pa spyi la'ang phan pa cher byung ngo." In Guru Tashi: 167.

62 For more on the connection of Nupchen to black magic see (Cantwell 1997, pp. 107-8, n. 5).

63 See $b k a^{\prime}$ shog rgya bo che 20a-21b. 
that emerges from these accounts is that of a scholar, but also of a powerful protector of the Buddhist teachings, who will do anything in his power to protect them. ${ }^{64}$

His works, or, we must say, the few that have survived, such as the Lamp for the Eye in Meditation or The Armor Against Darkness (mun pa'i go cha), ${ }^{65}$ a commentary on the main text of the Anuyoga tradition, the Sütra of the Gathered Intentions (dgongs pa 'dus pa'i mdo), reveal a remarkable intellectual, one who was well-versed in a wide variety of Buddhist contemplative traditions. His texts are filled with constant citations from hundreds of Buddhist scriptures, as well as the works of other Buddhist intellectuals from India and China, offering the most comprehensive window to the textual and intellectual world of Tibet during that period. ${ }^{66}$

According to various accounts, Nupchen wrote the Lamp in the early 10th century at the age of $61^{67}$ to atone for all the negative actions he engaged in to protect the Dharma during the political and military upheaval that followed the collapse of the Empire. He also claims to have written the text in order to defend the emergent Great Perfection from claims of being a mere Tibetan copy of Chinese Chan, a line of attack that will be used by later Tibetan scholars such as Sakya Pandita. ${ }^{68}$

In the larger historical context, it is important to remember that Buddhism was imported into Tibet as part of the great military, economic, and cultural transformation that the Land of Snows underwent during the Imperial era, between the seventh and the ninth century, (618-842 CE), which culminated with the establishment of this foreign tradition as the official state religion in the eighth century. During this period, Buddhism was imported and strictly regulated by the state through a few sponsored monastic institutions that controlled what texts were to be translated, and what kinds of rituals and practices were allowed.

The collapse of the Empire in the ninth century $(842 \mathrm{CE})$, to which Nupchen had a front row seat, opened a brief but crucial period in the history of Buddhism in Tibet that has been traditionally labeled as the Tibetan Dark Age (a clear reference to the European Middle Ages) ${ }^{69}$ and that has been described in traditional Tibetan historiography, and by most contemporary scholars in the field, as a period of intellectual decay, in which Buddhism almost disappeared from the Tibetan plateau. The problem with this description is that while the notion of a Dark Age may accurately evoke the collapse of the state-sponsored, monastic-centered form of Buddhism introduced by the empire, it also obscures the creative and dynamic changes that Buddhism underwent in Tibet during the same period. It is possible to argue that liberated from the restraints of Buddhist orthodoxy imposed by monastic institutions and the no-longer-existent state, Tibetans (and Nupchen was a key participant in this process) were able to transform what had been a foreign religion imposed by the state into a vehicle that was able to express genuine Tibetan religious ideas and concerns: Buddhism during the Dark Age became

64 For the complex intersection of Buddhism and violence see (Dalton 2011).

65 Kapstein has some doubts about the attribution of this work to Nupchen. Although I agree with Dalton in considering this a work by Nupchen, more research on this topic may bring some light to the issue of its authorship. See (Dalton 2016; Kapstein 2017).

66 The Lamp also offers an invaluable widow to the textual world of Buddhism in Tibet before the collapse of the Empire. The Lamp includes close to 750 quotes from almost 150 different sources, many of them no longer extant, or that have only survived in a fragmentary state. Nupchen quotes from sūtras like the Lankkāvatāra, Avatamsaka, and the Perfection of Wisdom Sūtras (Prajūāpāramitā); Nupchen also quotes more than 50 different Chan masters whose names only survive in the Lamp and in Dunhuang sources. There has been some scholarly work on some of these sources, particularly by Japanese scholars on the Chan chapter, and by others on the Great Perfection one, but there has not been a systematic attempt to trace all of the quotes of the text back, at least when possible, to their original sources. Donati (2006) and Esler (2018) have both translated this massive work.

67 See $b k a^{\prime}$ shog rgya bo che 20a-21b. See a discussion and a translation of this critical passage from the Bka' shog rgya bo che in (Lopez 2014, pp. 79-80).

68 On Sakya Pandita's attacks to the Great Perfection see his Clear Differentiation of the Three Vows (Tib. sDom gsum rab dbye), fol. $25 \mathrm{~b}$.

69 For a discussion on periodization in Tibetan history see (Cuevas 2006; Dalton 2011; Lopez 2014). On the use of the label 'Dark Age' to describe this period of Tibetan history see (Snellgrove 1987, p. 464; Kapstein 2000, pp. 10-17; Denwood 2010, p. 1; Manchester 1992, pp. 3-5; Lopez 2014, pp. 35-58). 
Tibetan Buddhism. As we will see, doxographies like the Lamp played a very important role in this creative process.

\section{The Lamp for the Eye in Meditation}

In my brief overview of early Indian, Chinese, and Tibetan doxographies we have seen the tension at the heart of the genre: On the one hand, doxographies were conservative tools that tried to preserve the unity of the Buddhist tradition in the face of astonishing and sometimes contradictory views, while, on the other hand, they also offered a vast amount of room for creativity and innovation, as new ritual and doctrinal systems would be added to the older ones.

Before we focus on the Lamp, it is important to point out that Nupchen, just like some of the scholars we have explored earlier, developed a second doxographical system during his lifetime, which can be found in his other major surviving work, the Armor Against Darkness (mun pa'i go cha). This commentary on the Sütra of the Gathered Intentions, a key Anuyoga text, clearly engages with the previous Indian classifications of these ritual and contemplative systems as elaborated by Buddhaguhya and Vilāsavajra in India, and the Garland in Tibet. Nupchen, though, argues in his Armor Against Darkness for a nine-vehicle classification that includes the Great Perfection (as Atiyoga) as a separate vehicle, something that none of the previous systems had proposed.
1. Śrāvaka
2. Pratyekabuddha
3. Bodhisattva
4. Kriyā
5. Ubhayā
6. Yoga
7. Mahāyoga
8. Anuyoga
9. Atiyoga $^{70}$

In fact, van Schaik has argued that Nupchen's doctrinal classification in the Armor Against Darkness may be the first instance of the nine-vehicle system found in Tibet. ${ }^{71}$ As Dalton points out, the Garland and Pelyang's text "divide their highest class of Mahāyoga into three 'techniques' (tshul) or 'stages' (rim) of development, perfection, and great perfection. In the writings of Nupchen, these three stages are enshrined as three separate classes"..$^{72}$ What is remarkable in Nupchen's classificatory system in the Armor is that it shows that he is part of a contemplative and textual movement in Tibet that is arguing for the unique nature of the Great Perfection, a movement that wants to separate the Great Perfection from the earlier tantric ritual and contemplative stages, transforming it into its own vehicle. In the case of the Armor, though, Nupchen seems to tackle the Great Perfection within the specific context of Indian Buddhism, while in the Lamp, as we will see, he is more concerned with establishing the Great Perfection in the much larger context of Buddhist contemplative practices across Asia.

The Lamp is divided into eight chapters $\left(l e^{\prime} u\right)$, but has its core in chapters four through seven, where, in a hierarchical form, four different Buddhist vehicles are explained. The four vehicles and their degree of non-conceptuality are, as follows: the Gradual Approach (tsen men rim gyis 'jug pa), which describes the traditional Mahāyāna textual and scholastic tradition coming from India and represented mainly by the Yogāea ra-Madhyamaka school; the Instantaneous Approach (ston mun cig car

\footnotetext{
(Dalton 2005, p. 140).

71 See (Van Schaik 2004, p. 188). Germano has suggested that the nine vehicle doctrinal classification may be a Tibetan indigenous interpretation of the Buddhist path that is based on the Tibetan myth of the nine-runged ladder that connects heaven and earth (in David Germano's unpublished manuscript Mysticism and Rhetoric in the Great Perfection (rDzogs Chen $\}$ ). For the Tibetan indigenous myth, see (Karmay 1998, p. 252).

72 (Dalton 2005, p. 140)
} 
'jug pa), represented by Chinese Chan; Mahāyoga (rnal 'byor pa chen po), which reflects the new tantric developments that had become popular in India starting in the seventh-eighth century (particularly in the Guhyagarbha Tantra); and Atiyoga ( $r d z o g s$ pa chen $p o$ ), a new contemplative system that reflects an innovative Tibetan understanding of Buddhist doctrine and practice.

For Nupchen, the four Buddhist systems share something in common, an acceptance of the notion of "non-conceptuality" (Skt. avikalpa; Tib. mi rtog pa) as the defining characteristic of meditation. What allows him to differentiate between the various systems and hierarchically classify them is their methods (thabs) to reach that state of non-conceptuality, and their philosophical views (lta ba) or descriptions of that state. For Nupchen, each tradition has an increasingly subtler understanding of the notion of non-conceptuality, and therefore a more profound understanding of the nature of the meditative experience.

\section{Defining and Comparing: Meditation and Non-Conceptualization}

In a section dedicated to taxonomy and comparison in the chapter "When the Chips are Down" of his book, Relating Religion, Jonathan Z. Smith explains how his early interests in botany and fascination with taxonomy led him directly to a concern with comparison. For Smith, "[p]ut simply, taxonomy seemed a comparative enterprise which sought similarity across obvious individual variations and which asserted significant difference even in the face of apparent resemblances."73 For Smith, comparison and classification are inseparable, since "comparison is never a matter of identity. Comparison requires the acceptance of difference as the grounds of its being interesting, and a methodical manipulation of that difference to achieve some cognitive end." 74

Smith's remarks will help us frame Nupchen's goal in Chapter 3 of the Lamp, in which he compares and classifies the four Buddhist contemplative systems discussed in the text (i.e., Gradual, Sudden, Mahāyoga, and Atiyoga). Nupchen's classification implicitly acknowledges the "acceptance of difference", since, in his view (i.e., in the Buddhist view), there is place for diversity of interpretations of the Buddhist path. At the same time, Nupchen also engages in a "methodological manipulation of that difference in order to achieve a cognitive end"; in this case, to establish a hierarchy and to impose the superiority of the Great Perfection over other Buddhist traditions.

In terms of the structure of the text, Chapter 3 is, without a doubt, the most important in Nupchen's Lamp. ${ }^{75}$ If Chapters 1 and 2 offer a general introduction to the practice of meditation and Chapters 4 through 7 are a detailed and individualized discussion of each of the four contemplative traditions, Chapter 3 reveals the methodological rationale behind the structure of the whole text. As Dalton and van Schaik have argued, Chapter 3 is "a microcosm of the text as a whole". ${ }^{76}$

\subsection{The Avikalpapraveśa-Dhārañ̄ and "Non-Conceptuality" in Tibet}

In Chapter 3 of the Lamp, Nupchen, in a very systematic way, describes the methodology behind the classification that will unfold in the following chapters. For Nupchen, all Buddhist systems share something in common, which will allow him to compare and, at the same time, rank them, as their different understandings (or should we say Nupchen's interpretation of their understanding) of that which they have in common is what gives him the ability to position them. What they have in common is their acceptance of the notion of "non-conceptuality" (Skt. avikalpa; Tib. mi rtog pa) as the defining characteristic of the Buddha's enlightened experience. What sets them apart is how they approach that state (their contemplative methods; Tib. thabs), and how each tradition understands it (their philosophical views; Tib. lta $b a$ ).

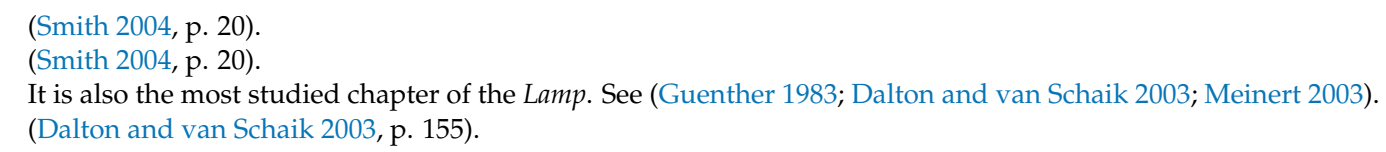


Although from its very early stages Buddhism had considered the Buddha's experience of enlightenment as being a non-conceptual, non-discursive, direct experience of the nature of reality, the emphasis on identifying non-conceptuality as the defining characteristic of Buddhahood seems to have taken hold within the Indian Siddha movement. ${ }^{77}$ The notion of 'non-conceptuality' played a very important role in many of the philosophical debates about the nature of enlightenment during the period of the early introduction of Buddhism in Tibet. ${ }^{78}$ It was at the heart of the so-called Samyé Debate. ${ }^{79}$ A text that played a key role in the introduction of this concept into Tibet was The Supreme Dhāran̄ī of Entering into Non-Conceptuality (Skt. Āryāvikalpapraveśa-dhāraṇī; Tib. 'phags pa rnam par mi rtog par 'jug pa zhes bya ba'i gzungs). ${ }^{80}$ Ueyama and Meinert argue the very important role that this scripture played in the dissemination of Buddhism from Central Asia into Tibet. ${ }^{81}$ Its importance can also be seen in the influence that the text had on the thought of some of the most important figures of Tibetan Buddhism during its early stages of introduction onto the Tibetan plateau, such as the Indian scholar, Kamalaśila, who wrote a commentary on this scripture (phags pa rnam par mi rtog par 'jug pa zhes bya ba'i gzungs kyi rgya cher 'grel pa), ${ }^{82}$ and the Chinese monk, Hashang Mahāyāna. ${ }^{83}$ The Dunhuang manuscript, Pelliot tibétain 116 (PT 116), a text that reflects Nupchen's understanding of the Chan tradition, also quotes the text.

In the Āryāvikalpapraveśanāmadhāranī scripture, ${ }^{84}$ the historical Buddha is teaching the importance of entering into the non-conceptual (rnam par mi rtog pa) state to an assembly of bodhisattvas, and teaches a fourfold, gradual approach to achieve it in which the practitioner cuts off the marks (spong $b a$ ) of conceptual thinking (rtog $p a$ ) by not engaging in whatever thoughts appear in the mind (mngon du gyur pa dag yid la mi byes pas). ${ }^{85}$ The four different stages that will lead the practitioner to the state of non-conceptuality are: (1) perception (dmigs pa); (2) non-perception (mi dmigs pa); (3) non-perception of perception (dmigs pa mi dmigs pa); and (4) perception of non-perception (mi dmigs pa dmigs pa). Meinert describes these four stages as follows:

In the first step of "perception" one cognizes all dharmas as the manifestation of "mere cognition" (rig pa tsam), that is, all dharmas are an expression of one's own mind [...] In the second step one cognizes "non-perception" of objects, to which the ordinary apprehension generally adheres [...] In the following step of "non-perception of perception" one trains oneself in the non-perception of the perception that "mere cognition" is non-existent. Since cognition is not possible without an object, cognition itself is also impossible [...] In the final step of "perception of non-perception" one perceives neither an apprehending subject not an apprehensible object. As subject and object are not of separate natures, non-duality may be realized. ${ }^{86}$

77 Higgins, discussing non-mentation (amanasikāra) in Indo-Tibetan Buddhism, a concept that is closely connected to the notion of non-conceptuality, argues, "The first widespread use of amanasikāra ('non-mentation') as a specific description of Buddhahood occurs within the Indian Siddha movement, although the term is not unknown in the Pali canon. The term and its Apabhramśa variant amanasiāra are associated in particular with the mystical songs (dohā or vajragīti) of Saraha, the most famous of the early Siddhas, and a cycle of texts attributed to his commentator Maitrīpāda (aka Maitrīpa, b. 1007 or 1010) referred to in Tibet as the Yid la mi byed pa'i chos skor or "The Cycle of Teachings on Non-mentation." See (Higgins 2009, pp. 255-56).

78 For a recent account of early discussion of "non-conceptuality" in Buddhism, see (Sharf 2018).

79 This is not the place to discuss at length the controversies surrounding the historicity of the Samyé Debate. For more on the historiography of this debate see (Demiéville 1952, 1970; Tucci 1956; Houston 1980; Ruegg 1992; Kapstein 2000).

80 On this scripture, see (Ueyama et al. 1983). See also (Meinert 2003).

81 (Meinert 2003, p. 177; Ueyama et al. 1983, p. 35).

82 Tib. rnam par mi rtog par 'jug pa'i gzungs kyi rgya cher 'grel pa. See (Jha 1937).

83 There is also the attribution to Vimalamitra of the cig car 'jug pa rnam par mi rtog pa'i bsgom don on the issue of non-conceptuality, although the attribution of this text is still a matter of debate. On this issue, see (Germano 2000; Faber 1989).

84 What follows is a summary of the text as described in (Ueyama et al. 1983; Meinert 2003).

85 (Ueyama et al. 1983, p. 35).

86 (Meinert 2003, pp. 182-83). 
The relevance of the Āryāvikalpapraveśa-dhāran̄i and, in particular, the importance of the notion of non-conceptuality as the essence of the enlightenment experience can be seen in the arguments of the two factions of the Samyé Debate. Hashang Mahāyāna, the defender of the Chinese Chan approach, argued for a complete suppression of all mental activity in order to reach this non-conceptual state. ${ }^{87}$ Kamalaśîla, on the other hand, in his commentary to the Áryāvikalpapraveśa-dhāraṇī, as well as in various references in his Bhāvanākramas, argued against Mahāyāna's position since non-conceptuality in the Āryāvikalpapraveśa-dhāraṇi did not simply imply a complete suppression of all thoughts, or even a negative view of mental processes, as the Chinese master argued, but a gradual process in which conceptual thoughts play a role in gradually entering into a final non-conceptual state. ${ }^{88}$

This is not the place to discuss the nuances of this debate. Here, suffice it to say that the Āryāvikalpapraveśa-dhārañ $\bar{\imath}$ and its notion of non-conceptuality had a very important role during the introduction of Buddhism in Tibet: It influenced some of the most important philosophical debates of the period and, as we will see, its fourfold path was probably the main influence for Nupchen's fourfold doxographical classification in the Lamp.

\subsection{Non-Conceptuality and the Fourfold Structure of the Lamp for the Eye in Meditation}

As we saw during our historical overview of the doxographical genre in Tibet in the previous section, Nupchen's classification in the Lamp is unusual in offering a fourfold scheme when the trend, particularly for the doxographical systems that originated in India, was towards a nine-vehicle system that was able to accommodate all the new ritual and contemplative tantric innovations of the eighth and ninth centuries. ${ }^{89}$ Although the origin of Nupchen's fourfold classification scheme is still not completely clear, Meinert makes a strong case when suggesting that Nupchen used the fourfold scheme of the Äryāvikalpapraveśa-dhāraṇi as a model for the one used in the Lamp. ${ }^{90}$ There is no direct acknowledgement by Nupchen of this influence, but all the evidence seems to point to the influence of the Âryāvikalpapraveśa-dhäraṇi on the structure of the Lamp: its importance in the introduction of the concept of non-conceptuality in Tibet; its influence in shaping some of the main arguments in the Samyé Debate; the fact that Nupchen is familiar with it, and quotes it in his text (including Section 3); and, finally, the similarities between the fourfold schemes in both texts. ${ }^{91}$

87 Ueyama argues that Hashang Mahāyāna's interpretation of non-conceptuality “took as the basic cause of birth-and-death the fact that thoughts (想xiang) grasp external objects, that is, that mental impulses arise. He held that awakening consists of cutting off the thoughts which are the cause of delusion and entering into no-examining/no-thought (Ch. 不思不观)”, (Ueyama et al. 1983, p. 36).

88 Ueyama argues that Kamalaśila "held that to deny all thoughts (manasikāra) is to deny even the correct examining or investigation ( pratyaveks $\bar{a}=$ so sor rtog $p a$ ) which is necessary for arriving at non-discriminative wisdom, that is, awakening. His criticism was that subsuming the conditions for becoming a Buddha under insight alone neglects the good practices of upāya and contradicts the Mahāyāna" (Ueyama et al. 1983, p. 36). Higgins writes in his discussion of the related issue of mentation (manasikāra) vs. non-mentation (amanasikāra) in the Samyé Debate that Kamalaśila's critique of Hashang Mahāyāna (although the Chinese master is not mentioned in the text, scholars agree that he is the recipient of Kamalaśila's criticism) "is that amanasikāra does not imply the suppression or cessation of mental activity but rather its progressive refinement through the gradual elimination of subjective distortions [...] Thus, Kamalaśila singles out mistaking amanasikära for the absolute non-existence of manasikāra as the major misinterpretation of this concept, a point he further clarifies in his Nirvikalpapraveśadhārañ $\bar{\imath}-t \grave{i} k \bar{a}$ [...] Conceptual meditation, in other words, is a necessary condition for non-conceptual realization", in (Higgins 2009, pp. 258-59). Gomez (2004) has defended a more nuanced understanding of Mahāyāna's positions that do include what some may call an acceptance of the Gradual Approach.

89 This is, in fact, the doxographical approach used by Nupchen in his Armor Against Darkness (mun pa'i go cha).

90 See (Meinert 2003). Dalton and van Schaik suggest a possible Chinese influence since scholars like the Korean scholar, Chegwan (d. 971), taught "'four methods of conversion' (hua-i): gradual (chien), sudden (tun), secret (pi mi), and indeterminate (pu-ting)" (Dalton and van Schaik 2003, p. 156).

91 Non-conceptuality also plays a very important role in a text quoted by Nupchen in the Lamp, Vimalamitra's Stages of the Path: "One who wishes to dispel obscuration and quickly achieve omniscience should concentrate on achieving quiescence and insight, thereby generating the altruistic mind. I, like a blind person, cannot demonstrate this, but relying on the words of Buddha and other scriptures, I will explain it. By right cultivation of quiescence and insight, non-conceptual intuition arises. Through the arising of this [non-conceptuality], one can abandon all obscurations and attain omniscience that is the result of the longtime practice of quiescence and insight. Therefore, one should strive for quiescence and insight. If one dwells in the state of non-conceptualization, one can see the reality of all things. It is certain that the purification of all obscuration and the achievement of omniscience is dependent upon causes; therefore, one should contemplate non-conceptualization. 
Nupchen structures the Lamp around the notion of "non-conceptuality" and identifies each of the different contemplative systems he discusses in the text with a different and increasingly subtler and refined understanding of that concept, with the Gradual tradition at the bottom, and Atiyoga, or the Great Perfection, at the top ${ }^{92}$ : The Gradual tradition's goal is the non-conceptualization of appearances (snang ba mi rtog pa), the one of the Sudden Approach is the non-conceptualization of non-appearances ( mi snang ba mi rtog pa), the Mahāyoga tradition attempts the non-dual non-conceptuality (gnyis su med $p a^{\prime} i$ mi rtog $\left.p a\right)$, and the Great Perfection, or Atiyoga, tradition's goal is the spontaneously present non-conceptuality (lhun gyis grub pa'i mi rtog pa). Let us explore how Nupchen explains each of these approaches to non-conceptuality, since they are key to the process of construction of doctrinal difference, as well as being central to Nupchen's project of building a new structural hierarchy that will allow him to claim the Great Perfection as the pinnacle of Buddhist contemplative practice.

\subsubsection{The Gradual Approach and "Non-Conceptualizing Appearances" (snang ba mi rtog pa)}

In order to describe the understanding of non-conceptuality of the Gradual Approach, Nupchen uses the Âryāuikalpapraveśa-dhāraṇī:

As for the "tsen men ${ }^{93}$ Gradual Approach, when [the practitioner] gradually abandons the four characteristics [which are] conceptualizing the nature, (conceptualizing the antidote, conceptualizing suchness, and conceptualizing the attainment), [the practitioner] enters into the non-conceptual [state]. The Dhāran̄ī of Non-Conceptuality (i.e., Avikalpapraveśa-dhāraṇī) says: "The people who want the wish-fulfilling jewels must use their minds to excavate under the extremely solid rock in order to see them. [So when people excavate] under these rocks they [find] the three precious stones: silver, gold, and emeralds. Under these four very firm rocks, all of them excavate [some more] and obtain the wish-fulfilling jewel, which emerges as the perfection of everything for the sake of self and others. [Similarly, those who want to reach] the non-conceptual [state] should free themselves from the four conceptualizations: conceptualizing the nature, conceptualizing the antidote, conceptualizing suchness, and conceptualizing the attainment. If [the practitioner] meditates about suchness without creating existents (yod pa) [the practitioner] will accomplish the three characteristics". They gradually meditate on the three gates of emptiness itself (stong pa nyid), without signs (mtshan ma med pa), and without aspirations (smon pa med pa), and they also meditate [using the techniques] of Śamatha and Vipaśyanā. ${ }^{94}$

Kamalaśila, one of the main proponents of the Gradual Approach, argued the importance of mental processes (Skt. manasikâra; Tib. yid la byed pa) and conceptual thinking (Skt. vikalpa; Tib. rtog pa)

As one who reaches the top of a lofty mountain can see almost all the surrounding places, similarly, one who dwells in the state of non-conceptualization can see all things without obstacle or impediment. Therefore, one should contemplate on quiescence and insight." In (Jamspal 2000, p. 1).

92 In this same chapter, Nupchen sketches an alternative threefold non-conceptual classification that does not develop in the text. For a brief discussion of this alternative system, see (Dalton and van Schaik 2003, p. 154).

93 It is interesting to point out that Nupchen uses the Tibetan (rim gyis), as well as the Chinese term (tsen men), to designate the Gradual Approach. For the Sudden school he also uses both languages (Tib. cig car; Ch. ton mun).

94 Lamp 55.6-57.1: de la tsan med rim gyis 'jug pa ni/rang bzhin (56.1) la rtogs pa'i mtshan ma la sogs ba <dang gnyin po rtog pa dang/de kho na nyid la shrtogs pa dang/thob pa la rtog pa dang/> bzhi rim gyis spangs nas/mi rtog pa la 'jug pa ste/de yang mi rtog pa'i gzungs las/yid bzhin gyi nor bu rin po (56.2) che 'dod pa'i mis brag shin tu rsa zhing 'greg pa'i 'og na yid kyis rkos shig// rin po che 'di lta ste//(56.3) brag de'i 'og na/dngul rin po che dang/gser dang/rdo'i snying po'o/ / de dag la rin po che'i brag gsum//brag shin tu sra ba dang bzhi'i 'og nas/de yo brkos (56.4) pa dang/yid bzhin nor bu bdag dang gzhan don thams cad rdzogs par 'byung ba 'thob pa de bzhin tu/rnam par mi rtog pa 'dod pas/rang bzhin la rtog pa'i mthan (56.5) ma dang/gnyen po la rtog pa'i mtshan ma dang/de kho na nyid la rtog pa'i mtshon ma dang/thob pa la rtog pa'i mtshan ma de bzhi dang bral bar byas nas/mtshan (56.6) ma gsum po la de kho na yis yod la ma byas par bsgom na 'grub bo/ / zhes gsungs pas/rim par bsgom pa dang/gzhan stong pa nyid dang/mtshan (57.1) ma med pa dang/smon pa med pa'i sgo gsum rim par bsgom pa dang/zhi gnas lhag mthong la sogs pa bsgom pa'o//. 
as the starting point of the meditation path, as well the central difference with the Sudden Approach. In this tradition, then, we see a gradual abandonment of the process of conceptualization. ${ }^{95}$

\subsubsection{The Sudden Approach-Non-Conceptualizing Non-Appearances (mi snang ba mi rtog pa)}

According to Nupchen, the practitioners of the Sudden Approach do not need to begin meditative practice by engaging in conceptual thinking, since they are able to instantaneously enter into a non-conceptual state:

From the beginning, without alternating [methods], they train in the unborn ultimate [...] The entrance gate to the Sudden Approach has been explained by many teachers [such as] the Great Master Bodhidharma, who said "Turn in the correct direction and abandon conceptuality". When you abide in wall-gazing, ${ }^{96}$ there is no self and other. Common people and noble ones are one and the same. When abiding steadily, without moving, from then on, [you] will not go after words and teachings. [You] will abide in the state of the true meaning, where there is non-conceptualization, and no activity. ${ }^{97}$

The superiority of the Sudden over the Gradual is, according to Nupchen, based on the acknowledgment of the superiority of non-conceptuality over conceptuality as the starting point of contemplation. The problem, though, as Guenther pointed out, is that the Sudden Approach still "emphasizes the non-thematic [i.e., non-conceptuality] over and against the thematic [i.e., conceptuality] without realizing that experience is made up of both, the thematic and the non-thematic" ${ }^{\prime 98}$ Also, Nupchen critizices the Chinese Sudden tradition since, in their efforts to distance themselves from any type of conceptuality (and therefore, separate themselves from the Gradual Approach), they seem to have reified the idea of non-conceptuality almost without noticing it. ${ }^{99}$ As Guenther argues, "To speak

95 Nupchen describes it as a process in which the three types of conceptualization are gradually abandoned. These three types of conceptual discrimination (trivikalpa) are described in the Princeton Dictionary of Buddhism as: "(1) Intrinsic discrimination (svabhāvavikalpa), which refers to the initial advertence of thought (vitarka) and the subsequent sustained attention (vicāra) to a perceived object of the six sensory consciousnesses (vijñāna), that is, the discrimination of present objects, as when visual consciousness perceives a visual object. (2) Conceptualizing discrimination (abhinirūpanā̃vikalpa), which refers to discursive thought on ideas that arise in the sixth mental consciousness when it adverts toward a mental object that is associated with any of the three time periods of past, present, or future. (3) Discrimination involving reflection on past events (anusmaranavikalpa), which refers to discriminative thought involving the memory of past objects."

96 The term “wall-gazing" (lham mer gnas pa) refers to the Chinese term biguan ((壁觀), a key concept for the early Chan tradition as found in Bodhidharma's The Treatise on the Two Entrances and Four Practices (Ch. 二入四行论). As McRae has pointed out, though, "this concept has bedeviled the Chan tradition ever since its introduction [in that text]", since "ultimately, no one really knows what the term means. It only occurs in one other more-or-less contemporaneous source, a list of meditation practices recommended for beginners, where it occurs without explanation. (McRae, p. 30). As McRae points out, "eventually, the term came to be interpreted in the Chan tradition as referring to the act of sitting in meditation facing a wall, but as indicated in the discussion of Bodhidharma's hagiographical evolution above, it took some time for this meaning to take hold." (McRae 2003, p. 30). Meinert has argued that the Tibetan "lham mer gnas pa" should be translated as "abiding in luminosity", and offers a compelling case as to why this should be. In this case, though, I prefer to use "wall-gazing" since the term is used in the context of the Sudden teachings of Bodhidharma, and wall-gazing is the most common term to translate the Chinese biguan, which is what I think the Tibetan term is trying to translate (as Meinert herself acknowledges in her article). See (Meinert 2007, p. 255). I want to thank an anonymous reader for pointing out the need to clarify my use of 'wall-gazing' to translate the Tibetan 'lham mer gnas pai.'

97 Lamp 57.1-58.2: "ston mun ni cig car (57.2) 'jug pa ste/dang po nas re mos pa med par don dam pa ma skyes pa nyid la cig car slob te/shes rab kyi pha rol du phyin pa'i mdo las//dang po sems bskyed pa (57.3) nas rnam pa thams cad mkhyen pa nyid la yid bya'o/ / [...] mkhan <gzhung bstan/> po chen (57.6) po bo dhe dar mo ta ras bshad pa las/yang dag pa la phyogs shing rtogs pa spangs te/lham mer gnas na/bdag kyang med gzhan yang med/ma (58.1) rabs dang 'phags pa mnyam zhing gcig ste/mi 'gyur bar brtan par gnas na/de phan chad yi ge dang bstan pa'i rjes su mi 'brang ngo//'di ni yang dag (58.2) pa'i don gyi rnal du phab pa rnam par rtog pa med pa/zheng zhing bya ba med pa ste/de ni don la mi 'jug pa'o//".

98 (Guenther 1983, p. 356).

99 In the chapter dedicated to the Mahāyoga tradition, Nupchen criticizes the Sudden tradition for thinking that their view is "free from activity", but theirs is only a partial understanding of that concept, since it is not grounded in the superior non-dual view of Mahāyoga: "tshe de nyid la dbang bsgyur chen por 'gyur ba dang 'dra ste/ston mun dang (226.6) nga lta bas bya ba dang bral ba skad zer yang/theg pa chen po gnyis su med pa'i de bzhin nyid/mtha' yang ma mthong ste/don dam pa 'ba' zhig la mi stsol du zad de/(227.1) 'jag pa non bgrong pa mthar phyin nas de bzhin gshegs pas dbang bskur nas bzod rdo rje lta bu gnyis med shar nas sngags mthong ba dang/(227.2) de bzhin du da lta blo la brtan par cud zhig 'dug du ma btub kyang/gnyis su med pa rdo rje lta bu'i ye shes la slob pas/tshe 'di nyid la mthar thug pa'i phyir rol kyang (227.3) 
of something as never having come into existence is to have a concept of something, to which we may make attributions. This is precisely to be back in the thematic aspect of experience, and this the follower of the 'instantaneous' [i.e., Sudden] Approach will not admit."100

\subsubsection{Mahāyoga-Non-Dual Non Conceptuality (gnyis su med pa'i mi rtog pa)}

According to Nupchen, Mahāyoga tries to break free from this tension between conceptuality and non-conceptuality by embracing the non-dual nature of reality in which those distinctions disappear:

As for inner non-conceptual Thusness, the Mahāyoga tradition [proposes] that all phenomena have the radiance of intrinsic awareness [and therefore], the two truths do not exist, the agent does not act [upon phenomena], and it becomes luminous [naturally]. [All phenomena] are the non-dual sphere of wisdom. The Guhyasamāja Tantra says, "The object of meditation is not an object, the activity of meditation is not meditation, therefore, because objects do not exist, there is no object of reference in meditation." ${ }^{\prime 101}$

However, as Guenther argues in his interpretation of Nupchen's presentation of Mahāyoga's approach to non-conceptuality: "It is precisely this attempt to preserve the unitary [i.e., non-dual] character of experience as an interiority in which there is neither a 'within' nor a 'without' that prevents the experience from coming to grips with that spontaneity [of] pure experience". ${ }^{102}$ For Guenther, both the Gradual and Sudden traditions have an ontological approach to contemplation in which the practitioner objectifies reality during the practice of meditation. The Mahāyoga tradition is aware of that pitfall and focuses on non-duality, but in its effort to preserve that non-dual nature of the meditative experience, it does not leave space for the acknowledgement of the spontaneous and dynamic nature of reality. Although I find Guenther's interpretation compelling, he is also in many ways as much of an apologist of Nupchen's work, as he is an interpreter. While he may be right about Nupchen's definition of non-conceptuality within the Mahāyoga tradition, he also seems to ignore that Nupchen is responsible for the interpretative framework in which each of the traditions is defined and finally judged, and which will ultimately allow him to claim the superiority of the Great Perfection tradition.

\subsubsection{Atiyoya-Spontaneously Present Non-Conceptuality (lhun gyis grub pa'i mi rtog pa)}

Finally, Nupchen presents what he considers to be the highest vehicle, Atiyoga, or the Great Perfection, which would offer the supreme understanding of non-conceptuality, "non-conceptuality which is spontaneously perfect" (lhun gyis grub pa'i mi rtog pa):

As for the spontaneously perfected Thusness of Atiyoga, the Supreme Yoga, all appearing and existing phenomena are primordially self-radiant since they remain perfect in the perfectly pure sphere of self-emergent wisdom. As for the cause and the result, which are spontaneously perfected without any need to search [for them], this is the Great Self, where there is no movement, no particles, no names. So what is to meditate in the clear radiance where there is an intrinsic awareness that is not established, does not waver, is not tainted,

mi ‘byi char yang mi phod de/de ni lta ba'i don gzhi nas khyad par du 'phags pas rgyu'i theg pas thob pa'i byang chub sems dpa' nyid/'dir dang po sems bskyed pas (227.4) zil gyis gnon par gsungs yang/sems dang po skyes pa nas gnyis su med pa'i don la sems bskyed pas/stobs de las gyur pa ste/zhib tu phyis 'chad (227.5) do/".

100 (Guenther 1983, p. 357).

101 Lamp 59.3-59.6: "nang pa'i mi rtog pa de bzhin nyid ni/mah'a yo ga'i gzhung gis/chos thams cad ni rang rig par gsal ba nyid bden pa gnyis med pa/byed pa pos ma byas pa dang/yong gis 'od gsal ba/dbying ye shes gnyis su med pa ste/gsang ba 'dus pa las/dngos po bsgom pa med pa'i dngos//bsgom par bya ba bsgom pa med//de ltar dngos po dngos med pas//bsgom pa dmigs su med pa'o//zhes gsungs pas".

102 (Guenther 1983, p. 360). 
does not settle? What is there to recollect? There is nothing [...] Non-conceptuality is itself a [mere] concept. ${ }^{103}$

Here, the non-dual approach of the Mahāyoga tradition is superseded by an understanding of reality in which everything is spontaneously perfect, and therefore there is no need for any effort or practice to reach the stage of non-conceptuality. What allows Nupchen to make this claim is not only the unique understanding of non-conceptuality espoused by the Great Perfection, but also its non-dual, spontaneous nature, concepts that will be at the center of this new Tibetan tradition.

\subsubsection{Meditation and 'the Rungs of a Ladder'}

The structural similarity of Nupchen's system with the fourfold presentation of non-conceptuality in the Âryāvikalpapraveśa-dhāraṇi can be seen in Figure 1.

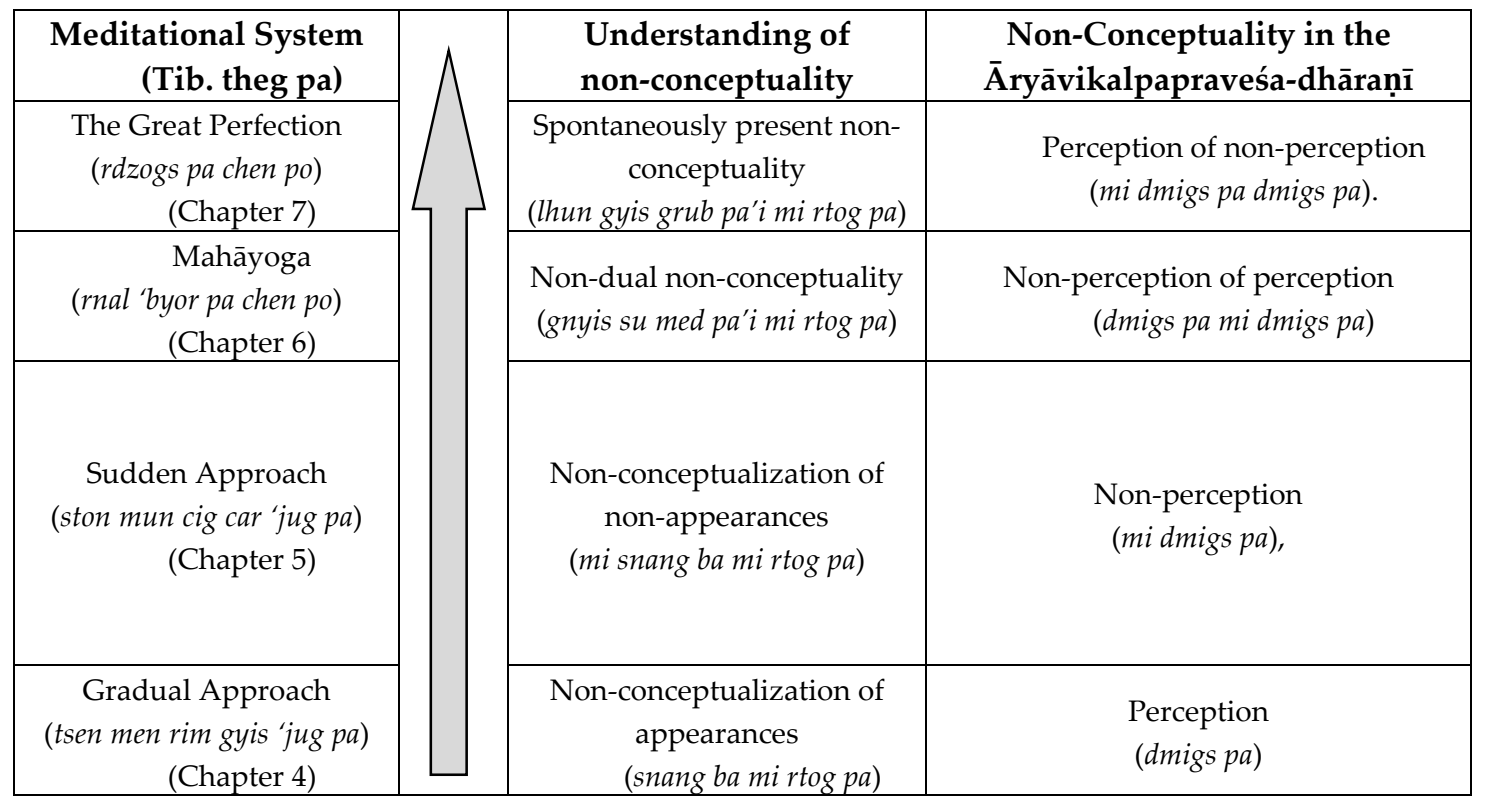

Figure 1. The Lamp for the Eye in Meditation and the Āryāvikalpapraveśa-dhāraṇī.

Nupchen seems to indicate that the four traditions articulate a gradual path in which the practitioner could follow in stages the contemplative techniques of each of the traditions in order to achieve the supreme form of non-conceptuality, that of the Atiyoga tradition. He insinuates as much in the text when he claims:

The differences between these [contemplative systems] are like the rungs of a ladder. Just as a ladder has higher and lower rungs, so are the differences between these four non-conceptualizations [of the Gradual, Sudden, Mahāyoga, and Atiyoga traditions]. ${ }^{104}$

Nonetheless, there is also an important tension at the core of the system. The overall gradual message implied with the image of the ladder resonates with the approach presented in the

103 Lamp 60.3-60.6: "a ti yo ga lhag pa'i rnal 'byor gyi lhun rdzogs de bzhin nyid ni//snang srid gyi chos so cog rang byung gi ye shes rnam par dag pa'i (60.3) klong du sel med par ye nas rang gsal ba la//rgyu dang 'bras bu ril ma btsal bar lhun gyis rdzogs pa ni/bdag nyid chen po pas/de la g-yo rdul ming (60.4) yang med pas/rang rig pa ma bzhag ma g-yos ma bslad ma zhugs par lhan ne lhang nge ye gsal bar ci zhig bsgom/ci zhig dran par byar yod de med/(60.5) med pa'i don de nyid kho na yod/de dang du len pa su zhig ste/ye mi rtog pa chen po la/snang ba bkag pa yang med la/de la rtogs pa med $\mathrm{de} / \mathrm{mi}$ rtog pa (60.6) nyid kyang bla dwags so//".

104 Lamp 60.6-61.1: "de dag gi khyad par skas gyi gdang bu bzhin te/dper na skas gdang la mtho dman yod par dang 'dra ste/mi rtog pa 'di bzhi yang khyad par yod <ston tsen mah'a a ti/>//." The same notion is repeated in the final colophon of the text in Lamp 500.4: "tsen ston mi dmigs nang pa'i mi rtog de bzhin nyid//lhun rdzogs mi rtog khyad par skas bzhin chud par bya'o//" Bold and italics are mine. 
Āryāoikalpapraveśa-dhāraṇī. The problem, though, emerges when Nupchen attaches each of the stages of non-conceptuality to a different Buddhist contemplative tradition. While all Buddhist traditions as described by Nupchen may share this notion of non-conceptuality, none of those traditions, besides the Great Perfection, to which Nupchen belongs, would agree with Nupchen's portrayal of their understanding of it, and they would, most certainly, not situate themselves in positions of inferiority vis-à-vis other traditions. They are all, from their respective points of view, perfect and complete contemplative systems, and it is only in the context of Nupchen's project that other systems are demoted. This tension is also accentuated by the fact that throughout the text Nupchen continuously undermines the idea of a gradual approach to his overall system when he keeps dismissing all of the other traditions with the exception of the Great Perfection, criticizing their approaches in each of the chapters.

\section{Conclusions: Comparison, Classification, and the Construction of Tibetan Buddhism}

Here, I would like to bring back Jonathan Smith's ideas in order to address the inherent tension in Nupchen's system (and of all doxographies for that matter). In the first place, Smith can help us understand the constructed nature of Nupchen's classification. For Smith, "Comparisons are not a given, they are the result of thought ... comparison does not necessary tell us how things 'are' ... like models and metaphors, comparisons tells us how things might be redescribed". ${ }^{105}$ Under this different interpretation of comparison and classification, we can see Nupchen's project not as a description of Buddhism during his time as existing "out there", but as a creative project in which Nupchen is reenvisioning what Buddhism could have been in Tibet. ${ }^{106}$ Secondly, for Smith, comparisons:

... bring differences together within the space of the scholar's mind for the scholar's own intellectual reasons [...] Comparison provides the means by which we 're-vision' phenomena as our data in order to solve our theoretical problems. Comparison, as seen from such view, is an active, at times even playful, enterprise of deconstruction and reconstruction which gives the scholar a shifting set of characteristics with which to negotiate the relations between his or her theoretical interests and data stipulated as exemplary. ${ }^{107}$

The notion of non-conceptuality allows Nupchen to bring together these four different traditions "within the space of the scholar's mind for the scholar's own intellectual reasons". These intellectual reasons can be seen as twofold. On the one hand, Nupchen wants to make sense of the variety of Buddhist contemplative systems that had made their way into Tibet up until his own time. On the other hand, he wants to establish the superiority of his own contemplative tradition, the Great Perfection, above all other Buddhist traditions. Definition, comparison and classification, using Smith's terms, offered Nupchen the tools to actively and creatively deconstruct the Buddhist tradition only to put it back together in a new, original way that responds not only to the historical developments of the Buddhist tradition over the centuries, but to the present historical context in which the Buddhist tradition was developing in Tibet.

As we have seen above, Nupchen lived during the so-called Dark Age period, and it might well be that it was under the cover of this darkness that Tibetans like him were able to liberate themselves from the restraints of Buddhist orthodoxy imposed by monastic institutions and the no-longer-existent state. Thus, it was in this post-Imperial period that scholars like Nupchen were not simply interested in importing and translating Buddhism wholesale, but have become fully engaged in the wider conversation that is taking place across Asia about Buddhist doctrine and practice. In the Lamp, we do

105 (Smith 2004, pp. 23-24).

106 In his unpublished 1996 lecture, "Why Imagine Religion", Smith offers a useful metaphor to understanding the function of Nupchen's text by saying that "maps are structures of transformation, not structures of representation". I believe this is a very useful image to apply to Nupchen's classification, since it really operates as an intellectual map that it is not simply trying to reproduce the Buddhist reality of Nupchen's time, but also to actively transform it.

107 (Smith 1990, p. 51). 
not only see a presentation of established Buddhist views across the continent, but a creative Tibetan attempt to transform what had been a foreign religion into a vehicle that expressed genuine Tibetan religious ideas and concerns.

As Smith also argued, "[T] he world is not a given, it is not simply 'there.' We constitute it by acts of interpretation. We constitute it by activities of speech and memory and judgment. It is by an act of human will, through projects of language and history, through words and memory, that we fabricate the world and ourselves". ${ }^{108}$ I believe that by looking at Nupchen's project through the lens of Smith, we can reenvision Nupchen's narrative, looking at it not as an inevitable, inner-driven, theological Buddhist interpretation of the tradition, but by understanding it in its very specific social and historical context, and especially as an attempt to construct a worldview that translated the needs of a new, evolving culture. Nupchen and doxographies like the Lamp were central to the creative transformation of Buddhism into Tibetan Buddhism.

Funding: This research received no external funding.

Acknowledgments: I want to thank the four reviewers, who kindly read my article and offered invaluable feedback. I also want to thank Jenifer Hu for all her help during the editing process.

Conflicts of Interest: The author declares no conflict of interest.

\section{References and Notes}

\section{Primary Sources}

Dpal dbyangs (Pelyang). Thugs kyi sgron ma (Lamp of the Mind). P5918.

Gnubs chen Sangs rgyas ye shes. 1974. Rnal byor mig gi bsam gtan, or, Bsam gtan mig sgron: a Treatise on Bhāvana and Dhyanna and the Relationships between the Various Approaches to Buddhist Contemplative Practice. Edited by S. W. Tashigangpa. Leh: Smanrtsis shesrig spendzod.

Gnubs chen Sangs rgyas ye shes. 1999. Sangs rgyas Ye shes rin po che'i Lo rgyus gnubs kyi bka' shog chen mo (vol. 42 of the Bka' ma shin tu rgyas pa). Chengdu: kaH thog mkhan po 'jam dbyangs.

Gnubs chen Sangs rgyas ye shes. Mun pa 'i go cha (Sangs rgyas thams cad dgongs pa 'dus pa mdo'i dka' 'grel mun pa'I go cha lde mig gsal byed mal 'byor nyi ma). In Rnying ma bka' rna rgyas pa, vols. 50-51.

Gu ru bkra shis. 1990. Gu ru bkra shis chos 'byung (Bstan pa'i snying po gsang chen snga 'gyur nges don zab mo'i chos kyi byung ba gsal bar byed pa'i legs mkhas pa dga' byed ngo mtshar gtam gyi rol mtsho). Beijing: Krung go'i bod kyi shes rig dpe skrun khang, p. W20916.

Kamalaśíla, Bhāvanākrama. Tibetan \& Sanskrit Sgom rim thog mtha' bar gsum bzhugs so/Kama la śi las mdzad. Leh, Ladakh: Dpal na lendra'i chos tshogs nas par du bskrun, 2006.

Padmasambhava. Man ngag lta ba'i 'phreng ba (Garland of Views). In Selected Writings (gsun thor bu) of Ron-zom Chos-kyi-bzan-po. Edited by 'Khor-gdon Gter-sprul 'Chi-med-rig Bibliography 589 'dzin. Smanrtsis shesrig spendzod, v.73. Leh: S.W. Tashigangpa, 1974. vol. 1, pp. 1-18.

Vilāsavajra. dPal gsang ba snying po'i 'grel pa rin po che'i spar khab slob dpon sgeg pa'i rdo rjes mdzad pa (sPar khab). In Commentaries on the Guhyagarbha tantra and other rare Nyingmapa texts from the library of Dudjom Rinpoche. New Delhi: Sanje Dorje, 1974. vol. 1, pp. 1-222.

\section{Secondary Sources}

Buswell, Robert E. 2004. Encyclopedia of Buddhism. Farmington Hills: Gale, Cengage Learning.

Buswell, Robert E., Donald S. Lopez, and Donald S. Lopez. 2014. The Princeton Dictionary of Buddhism. Princeton: Princeton University Press.

Cantwell, Cathy. 1997. To Meditate upon Consciousness as Vajra: Ritual 'killing and Liberation' in the rNying-Ma-Pa Tradition. In Tibetan Studies, Volume 1: Proceedings of the 7th Seminar of the International Association for Tibetan Studies, Graz, 1995. Wien: Verlag der Österreichischen Akademie der Wissenschaften.

108 (Smith 1987, p. 14). 
Chappell, David W., and Masao Ichishima. 1983. T'ien-T'ai Buddhism: An Outline of The Fourfold Teachings [T'ien-T'ai Ssŭ Chiao I]. Hawaii: University Press of Hawaii.

Cuevas, Bryan. 2006. Some Reflections on the Periodization of Tibetan History. Revue d'Etudes Tibétaines 10: 44-55. Dalton, Jacob. 2005. A Crisis of Doxography: How Tibetans Organized Tantra During the 8th-12th Centuries. Journal of the International Association of Buddhist Studies 28: 115-81.

Dalton, Jacob. 2011. The Taming of the Demons: Violence and Liberation in Tibetan Buddhism. New Haven: Yale University Press.

Dalton, Jacob. 2014. Preliminary Remarks on a Newly Discovered Biography of Gnubs Chen Sangs Rgyas Ye Shes. In Quintman, Andrew, and Benjamin Bogin. Himalayan Passages: Tibetan and Newar Studies in Honor of Hubert Decleer. Somerville: Wisdom Publications.

Dalton, Jacob. 2016. The Gathering of Intentions: A History of a Tibetan Tantra. New York: Columbia University Press.

Dalton, Jacob, and Sam van Schaik. 2003. Lighting the Lamp: The Structure of the Bsam gtan mig sgron. Acta Orientalia 64: 153-75.

Demiéville, Paul. 1952. Le Concile de Lhasa; une Controverse sur le Quiétisme entre Bouddhistes de l'Inde et de la Chine au VIII. Siècle de L'ère Chrétienne. Bibliothèque de l'Institut des Hautes Études Chinoises. v. 7. Paris: Impr. Nationale de France.

Demiéville, Paul. 1970. Recents Travaux Sur Touen-Houang. Toung-Pao 56: 1-95. [CrossRef]

Denwood, Philip. 2010. Tibetan Arts and the Tibetan 'Dark Age', 842-996 CE. Journal of Inner Asian Art Archaeology 5: 189-96. [CrossRef]

Donati, Valeria. 2006. The Lamp Is Burning Bright. Gnoseological Approaches and Soteriological Perspectives in Gnubs Chen Sangs Rgyas Ye Shes' Masterpiece. Naples: Università degli Studi di Napoli L'Orientale.

Dreyfus, Georges B. J., and Sara L. McClintock. 2002. The Svatantrika-Prasangika Distinction: What Difference Does a Difference Make? Studies in Indian and Tibetan Buddhism. Boston: Wisdom Publications.

Eckel, Malcolm David. 2008. Bhāviveka and His Buddhist Opponents. Harvard Oriental Series 70. Cambridge: University Press.

Eimer, Helmut. 1992. The Classification of Buddhist Tantras According to the Jñannavajrasamuccaya. Wiener Zeitschrift Für Die Kunde Südasiens/Vienna Journal of South Asian Studies 36: 221-28.

Esler, Dylan. 2018. The Lamp for the Eye of Contemplation, the bSam-gtan mig-sgron by gNubs-chen Sangs-rgyas ye-shes: Hermeneutical Study with English Translation and Critical Edition of a Tibetan Buddhist Text on Contemplation. Ph.D. dissertation, Université Catholique de Louvain, Ottignies-Louvain-la-Neuve, Belgium.

Faber, Flemming. 1986. The Council of Tibet According to the sBa Bzhed. Acta Orientalia 47: 33-61.

Faber, Flemming. 1989. Vimalamitra-One or Two? Studies in Central and East Asian Religions 2: 19-26.

Germano, David. 2000. The Seven Descents and the Nature of sNga' 'Gyur: The 'history' of rNying Ma Tantras. In The Many Canons of Tibetan Buddhism: Piats 2000: Tibetan Studies: Proceedings of the Ninth Seminar of the International Association for Tibetan Studies. Leiden: Brill.

Gomez, Luis. 2004. Encyclopedia of Buddhism. Edited by Robert E. Buswell. New York: Macmillan Reference USA/Thomson/Gale.

Gregory, Peter N., ed. 1987. Sudden and Gradual: Approaches to Enlightenment in Chinese Thought. Studies in East Asian Buddhism. Honolulu: University of Hawaii Press.

Gregory, Peter N. 2002. Tsung-Mi and the Sinification of Buddhism. Studies in East Asian Buddhism. No. 16. Honolulu: University of Hawai'i Press.

Guenther, Herbert. 1983. Meditation Trends in Early Tibet. In Early Ch'an in China and Tibet. Berkeley Buddhist Studies Series 5. Edited by Whalen Lai and Lewis R. Lancaster. Berkeley: Asian Humanities Press.

Hakeda, Yoshito. 1972. Kūkai: Major Works. Translations from the Oriental Classics. New York: Columbia University Press.

Halbfass, Wilhelm. 1988. India and Europe: An Essay in Understanding. Albany: State University of New York Press. Higgins, David. 2009. On the Development of the Non-Mentation (Amanasikāra) Doctrine in Indo-Tibetan Buddhism. Journal of the International Association of Buddhist Studies 29: 255-303.

Hodge, Stephen. 2003. The Mahä-Vairocana-Abhisambodhi Tantra: With Buddhaguhya's Commentary. London and New York: RoutledgeCurzon.

Hopkins, Jeffrey. 1987. Emptiness Yoga: The Middle Way Consequence School. Ithaca: Snow Lion Publications. 
Hopkins, Jeffrey. 1996. The Tibetan Genre of Doxography: Structuring a Worldview. In Tibetan Literature: Studies in Genre. Studies in Indo-Tibetan Buddhism. Edited by Roger R. Jackson, Geshe Lhundup Sopa and José Ignacio Cabezón. Ithaca: Snow Lion.

Houston, Gary. W. 1980. Sources for a History of the bSam Yas Debate. Sankt Augustin: VGH-Wissenschaftsverlag.

$\mathrm{Hu}$, Yao. 2014. The Elevation of the Status of the Lotus Sūtra in the Panjiao Systems of China. Journal of Chinese Religions 42: 67-94. [CrossRef]

Jamspal, Lozang, trans. 2000, The Stages of Meditation by Vimalamitra. Ladakh: Ladakhratnashridpika.

Jenkins, Keith. 2003. Re-Thinking History. Routledge Classics. London and New York: Routledge.

Jha, Ganganatha, trans. 1937, The Tattvasañgraha of Śāntarakṣita: With the Commentary of Kamalaśīla. Gaekwad's Oriental Series. No. 80, 83. Baroda: Oriental Institute.

Jones, Lindsay, Mircea Eliade, and Charles J. Adams. 2005. Encyclopedia of Religion, 2nd ed. Detroit: Macmillan Reference USA.

Kapstein, Matthew. 2000. The Tibetan Assimilation of Buddhism: Conversion, Contestation, and Memory. Oxford and New York: Oxford University Press.

Kapstein, Matthew. 2017. Book Review: The Gathering of Intentions: A History of a Tibetan Tantra. Journal of the American Academy of Religion 85: 559-61. [CrossRef]

Karmay, Samten Gyaltsen. 1988. The Great Perfection (rDzogs Chen): A Philosophical and Meditative Teaching of Tibetan Buddhism. Leiden-New York: E.J. Brill.

Karmay, Samten Gyaltsen. 1998. The Arrow and the Spindle: Studies in History, Myths, Rituals and Beliefs in Tibet. Kathmandu: Mandala Book Point.

Lopez, Donald S. 1988. Buddhist Hermeneutics. Studies in East Asian Buddhism. No. 6. Honolulu: University of Hawaii Press.

Lopez, Manuel. 2014. Bringing Light in to the Darkness: An Intellectual History of Tibet's Dark Age (842-978 CE). Virginia: University of Virginia.

Lopez, Manuel. 2018. The 'Twenty or Eighteen' Texts of the Mind Series: Scripture, Transmission, and the Idea of Canon in the Early Great Perfection Literature. Revue d'Etudes Tibétaines 43: 50-94.

Manchester, William. 1992. A World Lit Only by Fire: The Medieval Mind and the Renaissance: Portrait of an Age, 1st ed. Boston: Little, Brown.

Mcmullen, Matthew. 2016. The Development of Esoteric Buddhist Scholasticism in Early Medieval Japan. Berkeley: University of California.

McRae, John R. 2003. Seeing through Zen: Encounter, Transformation, and Genealogy in Chinese Chan Buddhism. Berkeley: University of California Press.

Meinert, Carmen. 2003. Structural Analysis of the bSam Gtan Mig Sgron: A Comparison of the Fourfold Correct Practice in the Āryāvikalpapraveśanāmadhāran̄ī and the Contents of the Four Main Chapters of the bSam Gtan Mig Sgron. Journal of the International Association of Buddhist Studies 26: 175-95.

Meinert, Carmen. 2007. The Conjunction of Chinese Chan and Tibetan Rdzogs Chen Thought: Reflections on the Tibetan Dunhuang Manuscripts Iol Tib J 689-1 and Pt 699. In Contributions to the Cultural History of Early Tibet. Leiden: Brill's Tibetan Studies Library, vol. 14, pp. 239-301.

Mestanza, Ferran. 2005. La Premiere Somme Philosophique Du Bouddhisme Tibetain. Origines Litteraires, Philosophiques et Mythologiques Des Neuf Etatpes de La Voie (Theg Pa Rim Pa Dgu). Revue d'Etudes Tibétaines Number 8: 84-103.

Mun, Chanju. 2006. The History of Doctrinal Classification in Chinese Buddhism: A Study of the Panjiao Systems. Lanham: University Press of America.

Pasang Wangdu, Hildegard Diemberger, Per K. Sørensen, and Xizang Zizhiqu. 2000. DBa' Bzhed: The Royal Narrative Concerning the Bringing of the Buddha's Doctrine to Tibet. Beiträge Zur Kultur-Und Geistesgeschichte Asiens. Nr. 37. Wien: Verlag der Österreichischen Akademie der Wissenschaften.

Ruegg, David Seyfort. 1981. Le ITa-Ba 'I Khaydpar de Ye-Shes-Sde. Journal Asiatique 1981: 207-29.

Ruegg, David. 1989. Buddha-Nature, Mind and the Problem of Gradualism in a Comparative Perspective: On the Transmission and Reception of Buddhism in India and Tibet (Jordan Lectures 1987). London: SOAS University of London.

Ruegg, David Seyfort. 1992. On the Historiography and Doxography of the 'Great Debate of bSam Yas. In Tibetan Studies: Proceedings of the 5th Seminar of the International Associaton for Tibetan Studies (Narika 1989). Edited by Ihara Shoren. Tokyo: Naritisan Shinshoji.

Sharf, Robert. 1995. Buddhist Modernism and the Rhetoric of Meditative Experience. Numen 42: 228. [CrossRef] 
Sharf, Robert. 2018. Knowing Blue: Early Buddhist Accounts of Non-Conceptual Sense. Philosophy East and West 68: 826-70. [CrossRef]

Silk, Jonathan. 2003. The Fruits of Paradox: On the Religious Architecture of the Buddha's Life Story. American Academy of Religion. Journal of the American Academy of Religion 71: 863-81. [CrossRef]

Smith, Jonathan Z. 1987. Playful Acts of Imagination. Liberal Education 73: 14-20.

Smith, Jonathan Z. 1990. Drudgery Divine: On the Comparison of Early Christianities and the Religions of Late Antiquity. Chicago: University of Chicago Press.

Smith, Jonathan Z. 2004. Relating Religion: Essays in the Study of Religion. Chicago: University of Chicago Press. Snellgrove, David L. 1987. Indo-Tibetan Buddhism: Indian Buddhists and Their Tibetan Successors. Boston: Shambhala.

Takahashi, Kammie. 2009. Lamps for the Mind: Illumination and Innovation in dPal Dbyangs's Mahāyoga. Ph.D. dissertation, University of Virginia, Charlottesville, VA, USA.

Tucci, Giuseppe. 1956. Minor Buddhist Texts. Serie Orientale Roma. v. 9, 43. Roma: Instituto Italiano per il Medio ed Estremo Oriente.

Ueyama, Daishun, Jeffrey Broughton, and Kenneth Eastman. 1983. The Avikalpapraveśa-Dhāranī: The Dharani of Entering Non-Discrimination. BBK 22: 32-42.

Van der Kuijp, Leonard. 1984. Miscellanea to a Recent Contribution on/to the Bsam-Yas Debate. Kailash 11: $149-84$.

Van der Kuijp, Leonard W.J. On the Sources for Sa skya Pạ̣ita's Notes on the "Bsam yas Debate". The Journal of the International Association of Buddhist Studies 9: 147-53.

Van Schaik, Sam. 2004. The Early Days of the Great Perfection. Journal of the International Association of Buddhist Studies 27: 165-206.

Van Schaik, Sam, and Kazushi Iwao. 2008. Fragments of the 'Testament of Ba' from Dunhuang. Journal of the American Oriental Society 128: 477-87.

Warren, Henry Clarke. 1973. Buddhism in Translations. New York: Atheneum. First published 1896.

Wu, Jiang, and Greg Wilkinson. 2017. Reinventing the Tripitaka: Transformation of the Buddhist Canon in Modern East Asia. Lanham: Lexington Books.

Zhmud, Leonid. 2001. Revising Doxography: Hermann Diels and His Critics". Philologus—Zeitschrift Für Antike Literatur Und Ihre Rezeption 145: 219-43. [CrossRef]

(C) 2018 by the author. Licensee MDPI, Basel, Switzerland. This article is an open access article distributed under the terms and conditions of the Creative Commons Attribution (CC BY) license (http:/ / creativecommons.org/licenses/by/4.0/). 